\title{
Roadwork: Offstage with Special Drama Actresses in Tamilnadu, South India
}

\author{
Susan Seizer \\ Scripps College
}

\begin{abstract}
The event was absolutely unique, and it was repeated every year. For the event (any event) unfolds simultaneously on two levels: as individual action and as collective representation: or better, as the relation between certain life histories and a history that is. over and above these. the existence of societies.
\end{abstract}

—Marshall Sahlins, Islands of History, 1985

\section{Mise-en-Scène}

Roads and streets are a common mise-en-scène for enactments of the Tamil popular theater genre known as "Special Drama." The obligatory opening comedy scene of these live performance events always begins with a young woman dancing in the middle of a road, a fantastic suspension of Tamil norms of conduct for women. The painted canvas backdrop for this scene displays a wide, generic road stretching off vertically into the horizon. The comic enactment that unfolds rapidly develops into an exploration of illicit love. An unknown young bachelor appears on the road, and all manner of shady business unspools between the young man and woman, including lewd banter. flirtatious spats, boasts laden with sexual innuendo, coy one-upmanship. cooing love songs, and eventually. elopement.

This opening scene is a dramatization, in a comedic mode, of the proverbial bad road for women. Its narrative content perpetuates and encourages a dominant association between public roads and the stigmatized reputation of actresses as public women. This essay concerns how such an association of ideas shapes Special Drama actresses" off stige lives and, in turn, how their practices "on the road" potentially refigure the terms of that dominant discourse.

At the core of this essay are five fieldwork narratives. These retell specific experiences I had researching Special Drama actresses' roads. Each experience helped me to better understand actresses' actions offstage; these were episodes in which I learned. in particular. how and why actresses create private, exclusive spaces in the midst of the Tamil public sphere. Each narrative speaks of 
one leg in the journey to or from a Special Drama. Together, the five narratives thus constitute a single composite journey, which begins in a calendar shop in town (the first narrative), then heads out, by van (the second) or by bus (the third), to the site of a Special Drama stage and its backstage spaces (the fourth), and finally returns home, on foot, to town (the final narrative). This journey provides an impressionistic map, drawn from my own experiences traveling with specific women on specific roads, of the offstage spaces inhabited by Special Drama actresses. That is, my narrative maps out lived, experienced spaces; it does not aim to be an objective account of things seen at a distance. ${ }^{2}$ Each of these lived spaces is charged, for me, and remembered here by me, with images of particular women and men of the Special Drama world, images charged as much by the flair with which the artists interacted with me as by the deft pursuit of their own image-making practices. ${ }^{3}$

I have preceded each narrative with theoretical and ethnographic material designed to help contextualize the narratives for the reader. I present the actresses' roadwork as a set of lived, adaptive practices that operate in relation to extant norms that define "the good woman" in contemporary Tamilnadu as categorically excluding actresses from its purview. When actresses manage to make their behavior indistinguishable from that of good women-in other words. when they appear to comply with dominant norms-might the norms themselves be somewhat altered by being stretched to accommodate these women? With this question in mind, I build on theoretical work concerning "everyday resistance," arguing that actresses creatively expand the category of good woman to include themselves. I see this expansion of given, exclusive categories of social acceptability as a particular strategy for dealing with social stigma. The theoretical import of this study, then, concerns the larger issue of the effective redress of stigma: I detail a strategy that operates under the appearance of collaboration with social norms while simultaneously subtly refiguring the norms themselves.

\section{How Special Drama Works}

The name "Special Drama" (in Tamil, Special Nātakam) refers to a unique organizational feature of this genre of popular theater: each artist is hired "specially" for every performance. There are no troupes in Special Drama: instead, each artist is an independent professional.

Artists enact known repertory roles-such as Hero and Heroine. Buffoon and Dancer-in a set repertory of plays. The plays themselves are known as "mythologicals," condensed treatments of familiar (primarily Hindu) myths that were modernized by the playwright Sankaradas Swamigal (1867-1922) at the turn of the century. ${ }^{4}$ The most frequently performed play in the Special Drama repertory is "Valli's Wedding." the story of the Tamil god Lord Murugan's marriage to his Dravidian second wife, Valli (his first wife is Aryan). The plays are musical dramas, involving long verbal exchanges in both poetic song and dramatic prose. A Special Drama requires a minimum of ten performers: six actors and four musicians. For the majority of plays, the cast includes two 


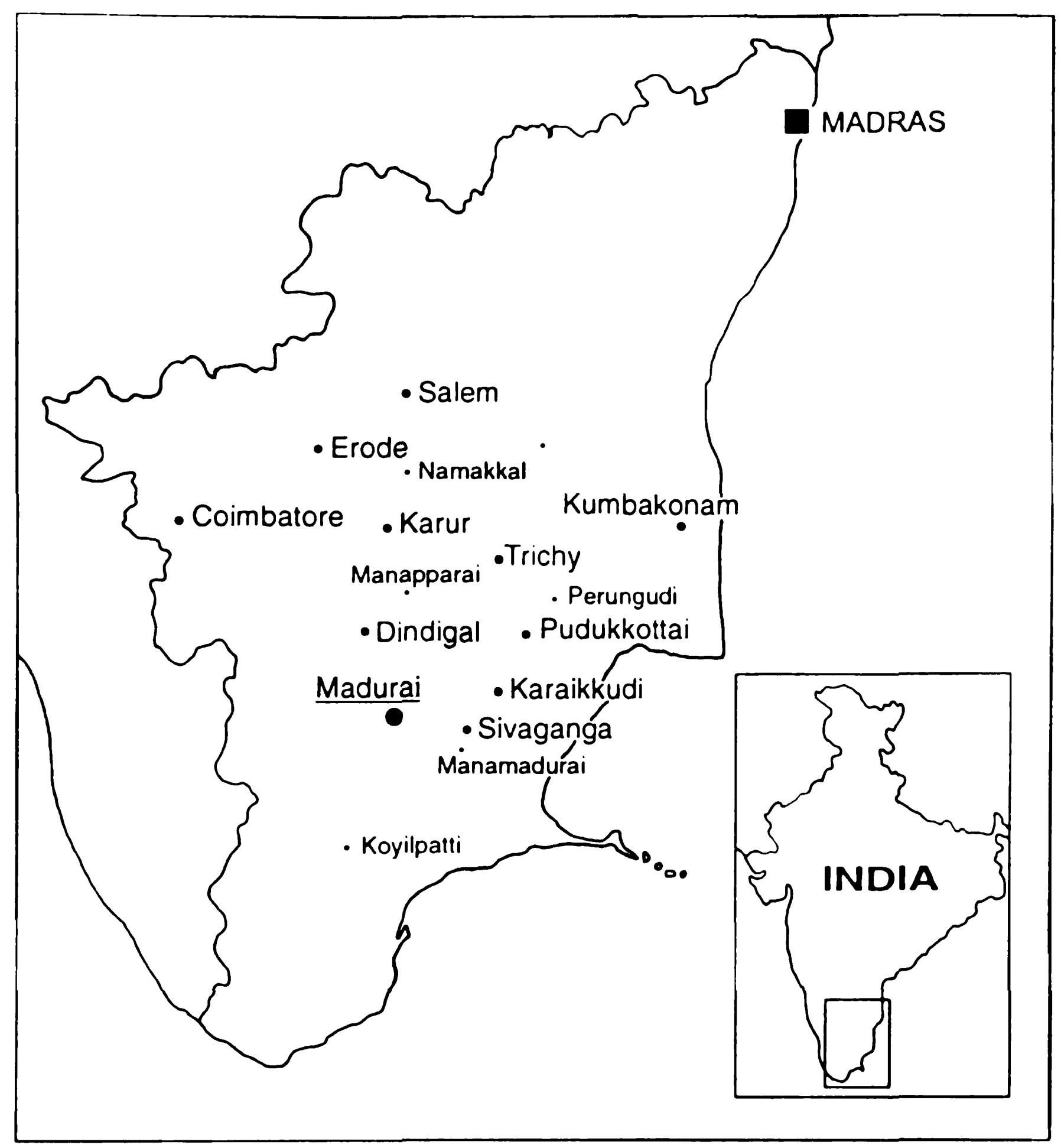

Figure 1

The state of Tamilnadu, showing the location of the 16 towns and cities in which actors associations are located. These are (in order of association membership size) Madurai, Pudukkottai, Dindigal, Karaikkudi, Karur, Salem, Sivaganga, Erode, Trichy, Coimbatore, Kumbakonam, Koyilpatti, Manapparai, Perungudi, Namakkal, and Manamadurai. Drawn by Catherine Brennan.

female actresses-one in the highly stigmatizing dancer role. the other in the relatively more prestigious heroine role-and four male actors.

An all-night Special Drama event comprises two main parts: two hours of comedy that take place from 10 p.m. to midnight and an ensuing six hours of dramatic narrative occurring from midnight to dawn. Such dramas are performed in villages and small towns throughout the eentral portion of the southern Indian state of Tamilnadu (see Figure 1). The Special Drama stage is generally a temporarily erected platform with palm-frond thatch for its three sides and ceiling. The plays are generally performed as entertainment for both the local audience and the particular deity being honored at a local temple festival. The local sponsors of any given Special Drama event are the villagers and townsfolk who hire 
the performers, which makes each event uniquely attuned to the desires of the local audience and the requirements of the particular location.

Hired independently, Special Drama artists who live in larger towns and cities must travel to a specified performance venue on a specified date either on their own or together with other artists also traveling from the same city. Artists previously unknown to each other, often from separate towns or cities, may meet for the first time standing opposite each other onstage, ready to perform their respective repertory roles. Each artist knows the role she or he is to play and is prepared to improvise as necessary; there are no directors, no rehearsals, and no companies for Special Drama. Each performance is truly a unique cvent.

Special Dramas are public events that rely on and engender a great deal of travel by both artists and audiences. During the drama season, the hot summer months of March through August, artists may appear on a different stage, in a different town or village throughout the state, every night. Thus, Special Drama performers must travel widely and be ready to handle unknown situations as they arise, both onstage and off. For actresses, as we shall see, such travel represents a problem whose social dimensions far outweigh its pragmatic difficulties.

Likewise, audiences travel to see dramas from a wide range of distances. In villages, not only do the majority of residents in the sponsoring village itself attend the drama but, in addition, villagers often invite their relatives, such that the drama, and the larger festival in which it partakes, generally becomes the occasion for an extended family visit. Besides villagers and their relatives, the general public - in practice, the residents of neighboring villages-is also welcome to attend, often swelling the ranks of any given village audience for Special Drama to roughly 3,000 people. These audience members sit, stand, or lie on the grounds of the village commons, on blankets and mats they bring with them from home.

Generally, three-quarters of this large audience are men. Attending such an outdoor, night-time public event is more socially fraught for Tamil women than men (see Seizer 1997b). The public sphere in Tamilnadu is largely a male domain, as I discuss further below; local women tend to guard against compromising their own reputations by declining to attend the event. Should they choose to attend, however, they will do so under the protective cover of a large familial group. Moreover, women and men watch the dramas from sex-segregated sides of the audience. The gendered propriety of such audience relations exists in marked contrast to the heightened intimacies of the mixed-gender scenes enacted onstage.

In the field of Special Drama, individual performers earn their professional reputations as well as their wages according to their desirability as performers in an economy of local audiences' preferences. Local men, from the given village or town planning a local festival, are the ones who decide which specific performers to hire for any given event. To book artists for their local drama, these men travel to one of the 16 cities in Tamilnadu out of which Special Drama actors currently work. ${ }^{5}$ 
Artists, both male and female, work out of these cities, though men and women clearly have different relations to the publicness of their profession and how such publicness affects their more personal, domestic lives in these cities. For example, many Special Drama actresses opt not to perform in venues that fall within a certain radius of their homes-usually within ten kilometers or so-and thus choose to consciously separate their professional personac from their domestic lives through overtly geographic boundaries. Male artists have no such concern and will perform anywhere. For actresses, such a restricted practice is continuous with the overall logic of the strategy I shall refer to below as the actresses' "roadwork." As should become clear, both actresses' choices not to perform locally and their attempts to minimize a tainting publicness when they do travel beyond their home locales are practices through which actresses attempt to maintain normative codes of decorum for Tamil women.

When they go out to work in public, Special Drama actresses have ingenious means of minimizing the effects of that publicness on their local, and more personal, lives. Actresses' strategic dealings with their exclusion from normative codes of feminine virtue are the focus of the remainder of this essay.

\section{Narrative One: Regarding the Gender Dimensions of Booking a Drama}

The arrangement of bookings and dates for Special Drama is a side of their business from which actresses often distance themselves, especially because such negotiations concern their own public mobility. Instead of taking bookings directly, an actress hangs her calendar in a booking shop. In 1993, there were five such shops in the city of Madurai, the long-established center for Special Drama. ${ }^{\circ}$ All were very male public spaces; several were printing shops in which booking artists' calendars was a side business, while for others such calendars were the main business. While the calendars of both male and female artists hang in these shops, only men are present physically, in the flesh that is, sitting around talking, checking on the dates of their next performances, or drumming up business for new bookings. Male representatives from a village or town interested in booking a drama come to the city of Madurai to peruse the posted calendars, check on the availability of specific drama artists, and converse with those in the know about the current crop of artists.

Men who, for a living, help these local sponsors make their drama arrangements are known as drama agents. Together, drama agents, drama sponsors, and male drama actors regularly hang out in and around the five booking shops in Madurai, all of which are located within a small two-block radius in the center of town. a little business district in which actors are kings of the road but which actresses only briskly pass through on their ways to and from performance venues (see Figures 2 and 3 ).

Inside the shops, the walls are lined with individual artist's calendars (see Figure 4 ). These calendars have a separate thin page for each day of the year. The pages make a square packet, which is stapled onto a cardboard backing where the artist's name is pasted as a heading, beneath which the artist's hust photo provides further identification and allure. Every artist's calendar provides 


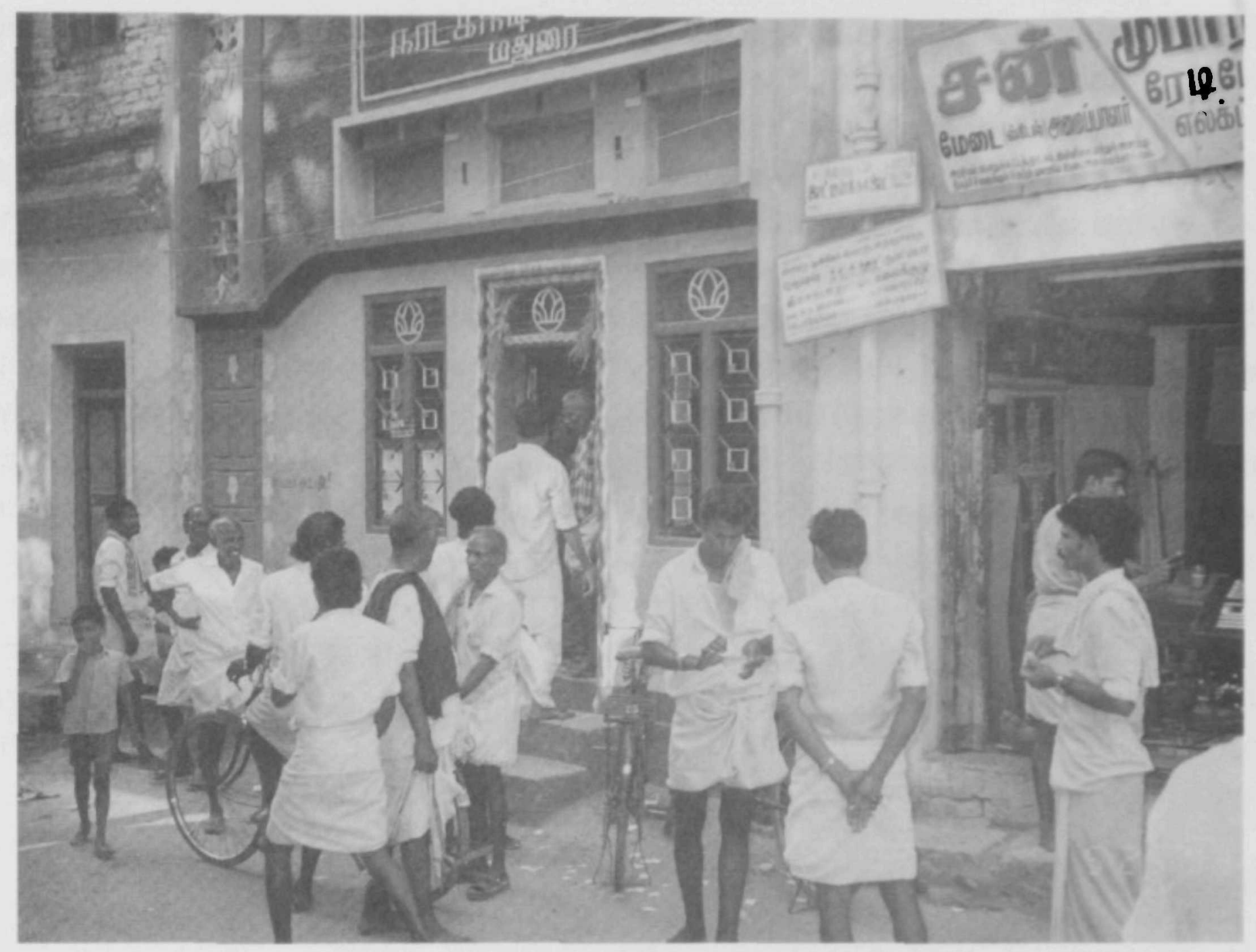

Figure 2

Artists in front of the actors association in Madurai, 1993.

a book of days that opens out under its personalized headboard like a skirt-or so it appeared to me.

Men interested in hiring an actress do not approach her directly but, rather, approach her calendar. An actress's calendar is in this way a material stand-in for her. It provides sponsors with a way to contract an actress without direct interaction and simultaneously allows the actress to absent herself from the negotiations. As in the process by which good Indian girls become brides, here men engage in negotiations in which a woman's person is implicated but not dialogically involved. ' While a man books an actress, she stays at home, an effigy of her (her personalized calendar) circulates in her stead.

Any man approaching an actress's calendar to book a drama may pick her effigy off the wall, handle it, peruse it, flip through its skirt, and read therein the unfolding story of the actress's public life: where she will be in the coming days, where she has been in the recent past, how busy this season looks, how in demand (or not) she is this season. Penned onto the back side of her calendar is the actress's performance fee, which is a private note from her, hidden from public view. If he selects her, he pens his name and his place-name directly onto the front of her calendar. Without her ever having to meet with him, he has arranged for her to come to his place, when he chooses, for a fee

The shop owner, who functions as a booking agent, has a certain financial stake in these negotiations, for he earns a small fee (three rupees was the going 


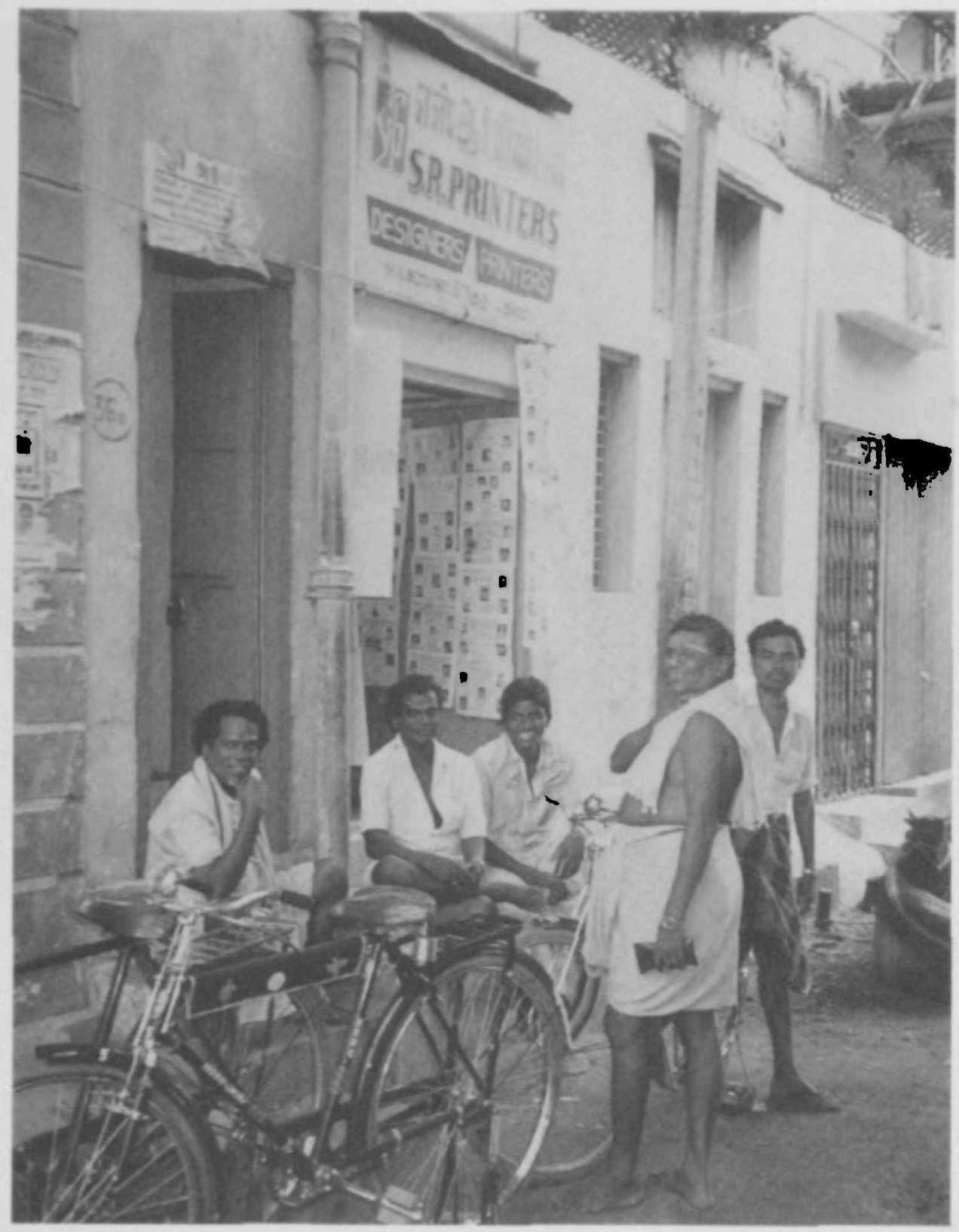

Figure 3

Artists outside a print shop in Madurai, 1993.

rate in 1993) every time an artist whose calendar he posts is booked for a drama. At least for the sake of business, then, the shop owner wants the calendars of popular artists in his shop. He needs to know whether or not a particular artist will actually attract sponsors' bookings; he needs to know each artist's value and reputation. When I asked one shop owner, Mr. Jeyaraman, how he ascertained this, he answered, "I'll ask them to sing. 'Show me how you sing,' I'll say, and they'll sing right here in the shop. I ask many people to sing before I put their calendar up." This surprised me because it was the first I had heard of such a practice. Our conversation continued:

Susan: Really? So, imagine that I want to hang my calendar here. Would you ask me to sing?

Jeyaraman: Oh no! No I won't. I won't ask this of women.

S: Why is that?

$\mathrm{J}$ : We can't ask a woman to come here and sing. Can we ask a woman to come sing in a public place? If this was a house, we might ask her, here we can't.

I was intrigued. We were talking about professional performers, stage actresses, the very women who do sing in public places-public women par excellencewere we not? I sat there in my sari with my black box of a tape recorder, asking 


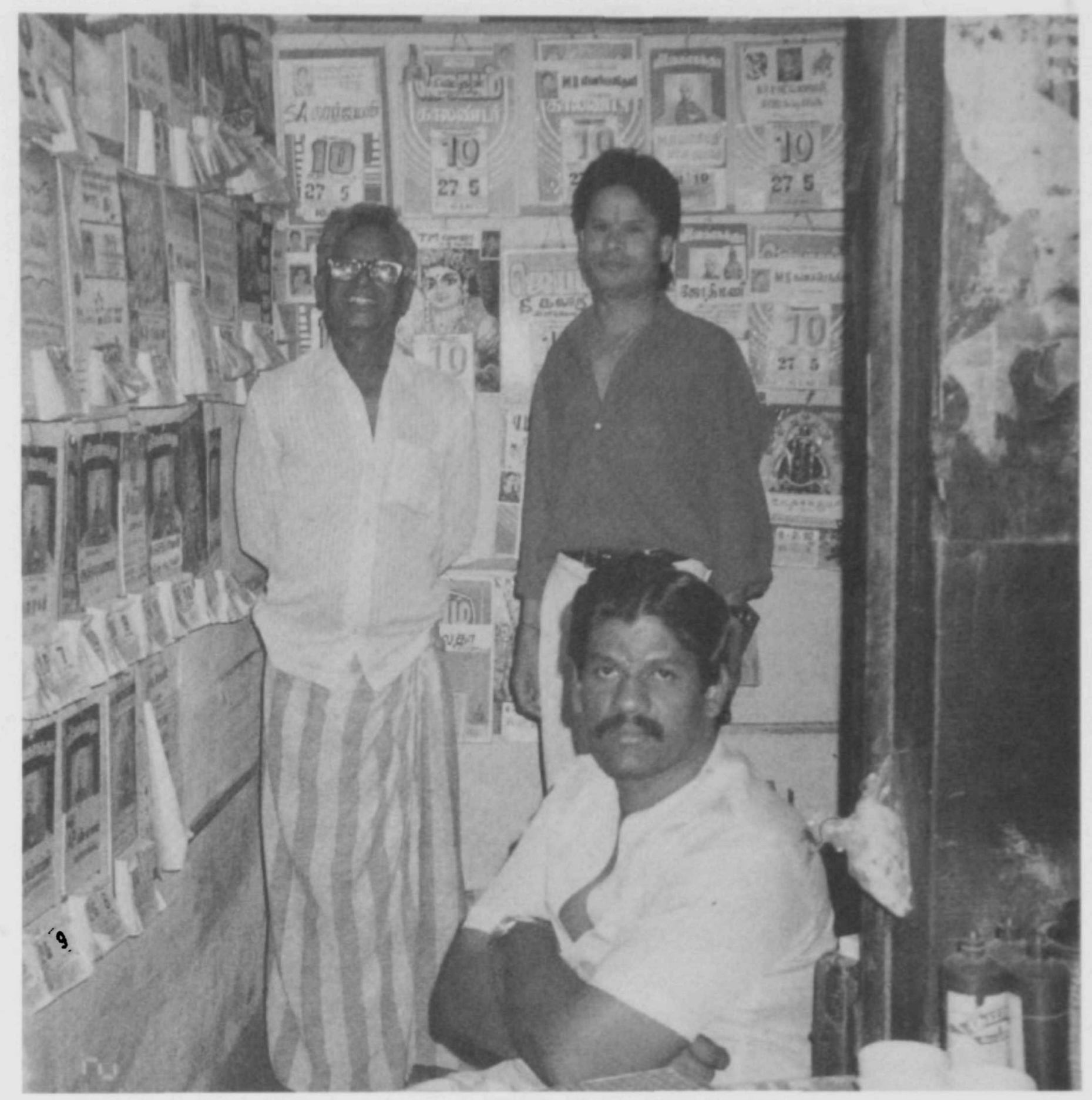

Figure 4

Jeyaraman's calendar shop, Madurai, 1992. Mr. Jeyaraman stands on the left.

him endless questions, feeling like a gender freak and a bit of a boor. Actresses might be public women professionally and by night, but in their local day-to-day lives, close to home, they tried to maintain reputations as proper women. ${ }^{8}$ In the daytime, in their daily local lives, actresses would not come out to a public shop-the very shop where I currently sat and quite publicly acted the anthropologist, asking questions about these very gendered norms and practices- and perform publicly. I realized belatedly and somewhat sheepishly that, when he spoke about asking them to sing, Jeyaraman had been referring only to male artists, the kind of people who should be in shops like his.

Before I could even ask how it was, then, that he did ascertain the talents of an actress without asking her to sing, he volunteered the following: "Regarding women, if we want a critical assessment, that's easy many people will be going to see her and will be knowing about her. We can learn from so many people: they'll be saying, 'This is how she talks, this is how she acts.'So therefore I can guarantee her to any town." Even her booking agent, then. learns of an actress's talents only indirectly, through the eyes, ears, and words of other men who have 
seen and heard her on stage. Other men speak to him directly about her voice, or else they speak in and around his shop to other men hanging out in and around his shop. It is men, speaking among one another, who determine an actress's reputation, while she sits, quietly or not, at home.

\section{Work and the Internalization of Gendered Behavior}

Our internalized sense, our knowledge, of what "works" in any given social and cultural milieu is critical to our ability to act in ways that establish us as competent actors within that environment. Of course this truism holds true only insofar as we take into account locally shared perceptions and apperceptions of who "we" are, for everyone is socially situated, and it is through our actions that we continue that situating process. ${ }^{10}$ We hecome who we are-she or he becomes who she or he is - through the process of engaging in "the dialectic of the internalization of externality and the externalization of internality" (Bourdieu 1977:72). That is, in learning to be cultural actors, we both internalize the external configurations and realities of our environment and simultaneously act in relation to that external world based on our internal understandings, including our desires in relation to that world and our place within it.

In the course of such a dialectical engagement with the world around us, we invariably learn about our social standing in the terms that are locally meaningful. Thus, we learn that we are male or female and concomitantly the meaning of male and female where we live; or we learn that we are rich or poor and simultaneously what that means where we live; or that we are dark skinned or light skinned. blond or black haired, short or tall, and so on and simultaneously what each of these distinctions means where we live. Grasping these locally meaningful distinctions among persons entails understanding the behavioral norms associated with each distinction and category of personhood. Our culturally competent actions must also take account of these norms of conduct. For acting outside such behavioral norms threatens to shame us, and shame is a notoriously potent social corrective: "It is shame, that concern for the good opinion of one's neighbors and friends, which circumscribes behavior within the moral boundaries created by shared values" (Scott 1985:17). Shame engages when there is the possibility of a public exposure of transgression (as opposed to guilt, which arises when transgressions remain secret; see Geertz 1973:401) and is, thus, intimately connected to our ideas ahout the self and its relation to the world around us. Recently it has even been suggested that shame is one of the hasic human means of modulating our overall interest in the outside world, for the fear of self-exposure in public reduces any desire to explore the world (Sedgwick and Frank 1995:5).

The women whose lives I am concerned with in this essaly arc stage actresses. The identity of stage actress in India is fraught with social stigma. In Tamilnadu, the very term actress evokes a canonical specter of shame and travesty. Common Tamil words for actress simultaneously denote whore or prostitute. Kütti, küttiväl, täci, and tévatiyäl all mean "dancing girl or prostitute" (Fahricius 1972:505), "(derogatorily) mistress: concubine" (Cre-A 1992:349), or 
"dancing-girl devoted to temple service, commonly a prostitute; harlot, whure" (Tamil Lexicon 1982:1825). "The combined effect of such derogatory terms and the discourses that fuel their existence is to keep most "good" Tamil women from daring or desiring to be actresses at all. ${ }^{12}$ Belonging to the social category of woman in Tamilnadu - being a South Indian woman who is linguistically and culturally competent and aware of what it means to be a member of this gender in contemporary Tamilnadu-fundamentally entails knowing that being an actress is a shameful occupation and social identity. ${ }^{13}$

Some women do, however, take on this job. My fieldwork in Tamilnadu from 1991 to 1993 involved eliciting the life histories of over 75 actors and actresses in the field of Special Drama. ${ }^{14}$ All the artists with whom I spoke voiced the same primary reason for their engagement in the field: to earn a living. Secondarily, some developed a keen interest in the art of the theater, but the original impetus for their involvement was poverty. Economic realities are thus a central component in the social identity of these artists, and Special Drama actresses are invariably (or at least they were at the time they entered the ficld) poor women.

Caste and religion, the other overarching fields of socially salient distinctions that generally mark and situate people in Tamilnadu, have surprisingly far less impact on who becomes an actress than do economic realities. Special Drama actresses include women of every caste background. from Harijan to Brahmin, as well as members of the minority Muslim and Christian communities (in addition to those of the Hindu majority community). ${ }^{15}$ Ethnicity is likewise a negligible consideration, as long as the women speak Tamil, the language in which Special Drama is performed; I met Special Drama actresses whose mother tongues included Saurashtrian. Telugu, Malayalam. and Kannada, many of whom spent their childhoods in the states where thesc languages are primarily spoken (Maharashtra. Andhra Pradesh, Kerala, and Karnataka. respectively). Caste and ethnic background thus did not affect the ability of a woman to participate in Special Drama (though in select instances a particular background might prove to her advantage). ${ }^{16}$

The social descriptor that bears more weight in the initial picture of who an actress is in her world is education level: while actresses must be literate. the average level of conventional education attained by the actresses I interviewed was fourth standard (roughly equivalent to a fourth grade grammar school education in the U.S. system). This is not in itself terribly unusual among poor Tamil women. While this is not the case in the middle class or among higher castes, a majority of Tamil girls still leave school when a marriage prospect emerges because "her security will come from marriage rather than from her $\mathrm{em}$ ployment" (Dickey 1993:24). The age at which a marriage prospect emerges is itself highly variable, especially in the (preferred) case of endogamous arranged marriage in which the bride and bridegroom know each other as children. In addition, for poor families even the relatively low cost of a public school education can be prohibitive, and female children are often removed from school prior to any marriage prospect for financial reasons. Actresses' training for Special Drama involves informal arrangements with drama teachers, male elders in the 
field who write out the lyrics to songs and the texts of debates which the actresses must learn in order to occupy the repertory roles. Thus, literacy is reyuired to become an actress but not a high level of formal education.

Within a general context, then, in which women's education is frequently sacrificed to economics (and by extension to marriage). a family's decision to allow a daughter to become an actress is still quite extreme, for it effectively kills any young woman's eventual prospects of a "normal" marriage. By normal here I mean a marriage arranged between the bride's and groom's families. No self-respecting groom's family will agree to have a son marry an actress (and this often includes families of male actors!) because of the standard reputation of actresses as prostitutes noted above, a bride's chastity being her main cultural capital. The only "marriage" route generally open to actresses (to which rare exceptions do exist) is what is euphemistically referred to as "second marriage" and less euphemistically as becoming concubines or mistresses. The Special Drama actresses I spoke with confirmed what I myself observed through charting kinship relations in the acting community: 95 percent of these actresses were in "second marriages." To a remarkable extent, the continued use of derogatory Tamil terms to denote "actress" functions simultaneously as a self-fulfilling prophecy, as poor young women who become actresses to earn a living effectively also eventually become mistresses.

Thus, a woman's only compensation for the loss of social standing attendant on entering this profession is economic. Working as a Special Drama actress pays quite well in relation to other kinds of work available to this class of women in Tamilnadu. For example, a woman who works as a cook or a maid might earn Rs 75 per month, whereas working as an actress she might earn Rs 300 in one night (these were average figures in 1993). ${ }^{17}$ Such relatively high wages should not, however, give the impression that Special Drama actresses are well-off once they begin on this road. In theory it is possible for an actresses to accumulate a substantial income; in practice. while actresses do alter their economic situations through this work, they remain enmeshed in relations that substantially drain that benefit. ${ }^{18}$

Given all the considerations that must be taken into account in attempting to understand the road of the stage actress in Tamilnadu-and I use the term road here both metaphorically and quite literally - another level of consideration is also necessary. The bad name accorded Tamil stage performers notwithstanding (or perhaps because of it, for cven in a place where "the bad" does not have the "cool," sexy association that it has in many Western societies, heing "had" is nevertheless a social option for women who have few other social options), the stage here excrts a kind of ineffable allure, as it so often does. ${ }^{14}$ There is the glamour of theatrical makeup, costumes. and bright lights. There is the applause of the crowd. There is the temporary illusion of heing someone else. just for a night. of a release from the strictures of day-t()-day reality: the characters these actresses play include noble yueens and mythological goddesses. There is, thus, the possibility of movement out side of one's normal phere. both in moving physically beyond the spaces in which one normally engagess. including 
altering one's normal bodily postures and gestures, and in the expansion of the psychological and social spheres within which one normally engages others and the terms in which one is engaged by them.

All this can be both terrifying and exciting. When it is also a woman's way to make a living, she must be able both to tap into its extraordinariness and to find a way to normalize it to sustain her daily life. It is to the effects of such qualities of expansion and extended mobility in actresses' lives that I now turn, specifically to certain on-the-ground strategies actresses use to deal with the effects of "the dialectic of the internalization of externality and the externalization of internality" that characterizes their working lives.

\section{Narrative Two: Regarding Traveling to a Drama in a Private Conveyance}

Whenever they can, Special Drama artists travel to their performance venues in private rather than public vehicles. Older artists recall with nostalgia the days when they traveled in the pinnacle of secluded, enclosed, and luxurious worlds: they rode in "pleasures." Pleasure is the English word that artists still use to refer to the private automobile, the rented Ambassador TM "pleasure car" that used to pick up actresses at their own doors and take them directly to the performance sites. ${ }^{20}$

Very rarely are "pleasures" used by drama parties today. Instead, quite often artists pool their resources to hire private vans, the current means of avoiding public buses (see Figures 5 and 6). Such drama vans are crowded. Sometimes 16 people squeeze into a space designed for ten, where in addition the back seat is entirely taken up with artistic provisions: a large wooden foot-pedal harmonium, several drums, multiple rolls of painted canvas backdrops for scene settings, not to mention each of the actors' costume-filled suitcases. People have to sit practically on top of each other in these vans, often for many hours.

Nevertheless, the question of why artists adamantly prefer crowded private vans to public buses is obvious: public-private distinctions as markers of prestige and social status in Tamilnadu long predate both vans and buses. The reigning logic is familiar: more prestigious persons occupy more (and more private) space, while less prestigious persons occupy less (and less private) space.

To me, traveling with drama artists in a van always felt risqué. Suddenly the strict women's side/men's side rule's of public conveyances were lifted. The two requisite actresses in any Special Drama party would often sit side by side in the van in a two-person seat, but equally often they did not. My own presence could easily instigate multiple shifts: a woman certainly had to be seated next to me for reasons of propriety (so that I would not be forced to sit beside an unknown man), but then what about the other actress? She suddenly had increased mobility, without ever seeming to have asked for it. Inside a van, other sorts of allegiances and alliances, even intimacies. emerged casily.

Van interiors provide drama artists a means of moving through and across public roads while carrying a collective interiority, a protective group cohesiveness, with them. The world internal to the drama community crealtes a bubble of familiarity that stretches to the contours of every space the actors fill together. 


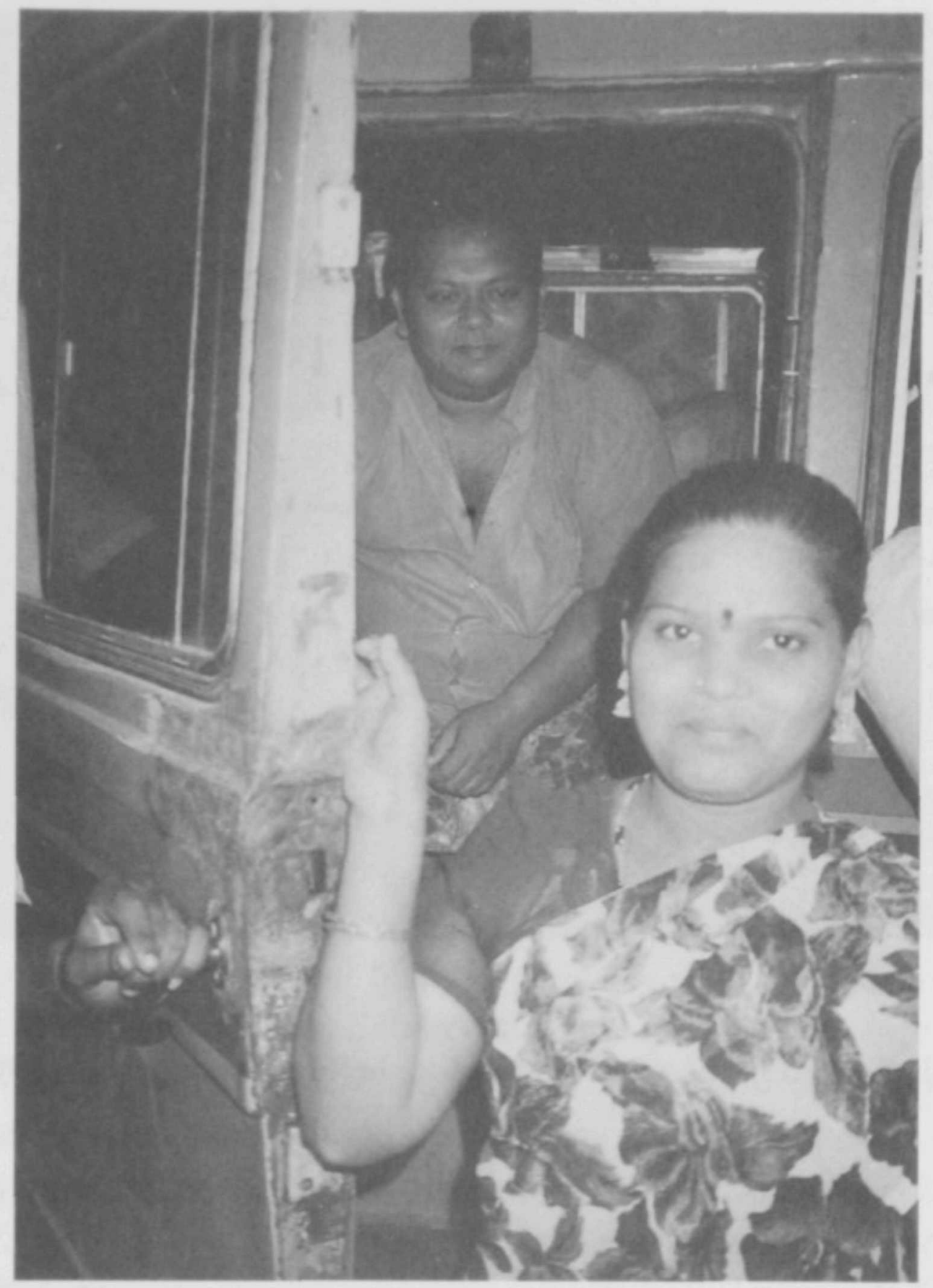

Figure 5

A Special Drama actress at the door to the van she will ride in to a Special Drama, 1998.

and in these cases it was the size of the interior of a van. I felt included in that "inside" familiarity when I rode with them. I felt freer there than almost anywhere else in Tamilnadu, engaged in a daring squeeze of closeness that was largely invisible to the outside world. I felt inside a family, of sorts, and it was a pleasure, too.

\section{Roads and the Externalization of Gendered Behavior}

Gayatri Spivak uses the metaphor of a roadblock to convey what she calls a difficult truth: that "internalized gendering perceived as ethical choice is the hardest roadblock for women the world over" (1995:xxviii). Spivak speaks of instances in which the internalization of gender norms and constraints has blocked the movement of individual women down particular paths (as in the lives of female characters in the short stories of Mahasweta Devi that Spivak has 


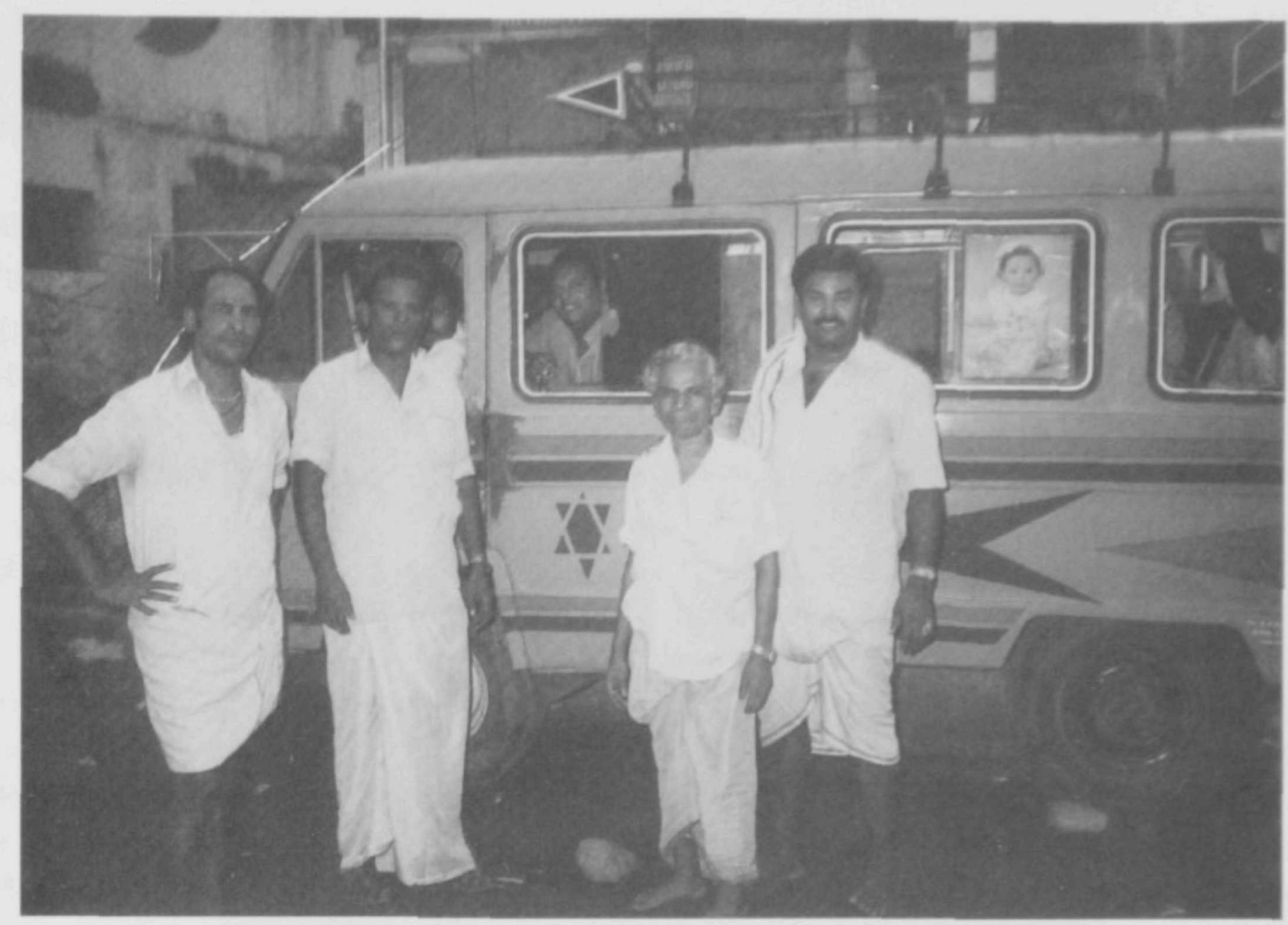

\section{Figure 6}

Male Special Drama artists standing before the same van, 1998.

translated), as well as blocked the progress toward social change of collective women's movements worldwide.

Partha Chatterjee (1993) offers a social history of India in which women's internalization of gender norms has had a strikingly opposite effect. Chatterjee stresses the important role that Indian women's internalization of a properly gendered self-image played in building the new Indian nation, arguing that beginning in the late 19 th and early 20 th centuries, the middle-class Indian woman's ability to internalize gender constraints eased rather than blocked her travels out into the world. Specifically, Chatterjee suggests that it is through their internalization of a self-image of virtuous domesticity that middle-class Indian women have been able to maintain respectability while venturing out into the public sphere: these good women are able to carry their home identities out into the world with them.

The strategy Chatterjee documents is an intriguing means of circumventing the censure on movement in public that confronts so many women. This ingenious strategy resolved "the women's question" for many nationalists: the middle-class Indian woman had simply to become so identified with the ideal spiritual and moral sphere of the home that these ideals would remain intact wherever she went she carries them with her, inside her. As Chatlerjec writes,

Once the essential femininity of women was fixed in terms of certain culturally visible spiritual qualities, they could go to schools, travel in public conveyances, watch public entertainment programs, and in time even take up employment 
outside the home.... This spirituality did not, as we have seen, impede the chances of the woman moving out of the physical confines of the home; on the contrary, it facilitated it, making it possible for her to go into the world under conditions that would not threaten her femininity. In fact, the image of woman as goddess or mother served to erase her sexuality in the world outside the home. [1993:130-131]

Moving in public, the respectable woman is able to carry with her an inner strength forged indoors.

The case, however, is quite different for those worldly women against whom Indian nationalism's ideal middle-class and educated women were explicitly defined. These are the women whom Chatterjee identifies as "sex objects" for the "nationalist male" precisely because they are seen as "other" than his mother/sister/wife/daughter. They are neither of his kin nor of his class. Such women do not erase sexuality, as do middle-class women; rather, they embody it: their very bodies "become the sanction for behavior not permitted" to women defined as properly feminine (Chatterjee 1993:131).

Actresses have long been the paradigm of such illegitimately public female bodies. ${ }^{21}$ This essay focuses on the problematic mobility of non-middle-class women who are considered not to have properly internalized the gender constraints that should have blocked their road, that should have kept them indoors (or at least working in and for the maintenance of the domestic sphere), and who are in this sense considered "bad" (as opposed to those whose complicity with such gendering renders them sweet, virtuous, innocent, or simple-again, see Dickey 1993:63; Spivak 1995:xxvii). Actresses are the very definition of the "bad" public woman, for, unlike the chaste loyalty of the good wife who reveals herself to only one man, the actress's profession requires that she willingly expose herself to the gaze of many unfamiliar men, brazenly stepping out into the limelight.

Publicness is at the core of the "bad" reputation of the stage actress. Writing of the bad reputation of stage actresses in North Indian popular theater, Kathryn Hansen notes that an actress is regarded as a prostitute simply by virtue of being in public:

The selling of sexual favors is not essential to the definition of a stage actress as a prostitute, either in North India or in other societies. Gender roles in this agriculturally based patriarchal society are defined in spatial terms, with women occupying private inside spaces and men public outer ones. Women are valued for their domestic labor and for their reproductivity, which must be controlled for the perpetuation of pure family and caste lines. Enclosure, whether effected by parda (the curtain or screen of a segregated household), by the canopy of a bullock cart, or by a veil or sari-end drawn over a woman's face. is conceived as necessary to preserve a woman's chastity and, by extension, her menfolk's honor. Since the social construction of gender places "good women" in seclusion, women who appear in public spaces (such as on stage) are defined as "bad," that is, prostitutes. Subjected to the gaze of many men, they belong not to one, like the loyal wife, but to all. [1992:22-23] 
In Tamilnadu, as well, a firm distinction between the public sphere of worldly activity and the domestic sphere of familial relations has long been central to the maintenance of a woman's, and thus her family's, good reputation. The North Indian paradigm of distinguishing between these spheres as "the home and the world" (ghar and bihar in Hindi) and marking them through the segregating practice of pardã (segregated living quarters) is perhaps more recognizable to Western readers (especially those familiar with the Bengali literature of Rabindranath Tagore and his 1915 novel The Home and the World [1985] or Satyajit Ray's subsequent film of the same name [1984]) than are South Indian practices of sex segregation and separate gendered spheres in public and in private.

For indeed, sex segregation continues to be the norm in most public venues in contemporary Tamilnadu. Restaurants, cinema halls, schools, buses, and places of worship all maintain separate sides for women and men. This is considered advantageous to both sexes and mutually protective; neither sex is prepared to deal with advances from strangers of the opposite sex. Women are of course wary of the sexual advances of unknown men, but men likewise fear the sexuality of unknown women. Two recent scholarly reckonings of the Tamil state of affairs, regarding the purported effects of female transgressive sexuality in public, reveal just how fundamental to contemporary Tamil gender relations is a notion of the inherent benefits of sex segregation:

Women possess a great amount of inherent power (cakti) - greater than men-but if this power is not limited and directed by a father, husband or brother it will lead to harmful events (such as illicit sexual liaisons) destructive to the woman's kin group and even to the fruitfulness of the land they live on (Wadley 1980: Reynolds 1980). [Dickey 1993:27]

The manner in which female sexuality is socially constructed in Tamil society. as elsewhere, is that an independent woman (i.e., a woman who is not under male domination) is sexually threatening and subversive. Even in popular Hinduism, those goddesses who are not under male domination are more feared as potentially destructive than goddesses with male consorts (Shulman 1980:144-57). This male anxiety over female sexuality is only heightened when the woman in question presents herself as a transgressor of socially prescribed norms, be they related to dress, space or anything else. [Pandian 1992:85. emphasis added]

Thus, even though parda does not take the same form in South India that it does in the North, a notion of the proper gendering of domestic and public spheres clearly informs Tamil sensibilities in fundamental ways.

The indigenous Tamil terms that best articulate and name Tamil configurations of properly gendered spheres have been explored in depth in A. K. Ramanujan's hugely influential studies of both classical Tamil poetry and poetics (1975, 1985) and popular folklore genres (1986, 1991a, 1991b). Ramanujan's work introduced into scholarly discussions of South India the indigenous terms that name the continuing distinction between domestic and public spheres in all realms of Tamil life. Ramanujan first translated the terms akam-"the 
inner part," or the Interior"-and puram-"the outer part, or the Exterior" (1975:101) - by following the usage of classical commentators discussing the division of poems in classical Tamil anthologies dating roughly from 100 B.C. to A.D. 250. Akam poems are love poems that speak the moods of generic, unnamed lovers; puram poems are "usually about good and evil, action, community, kingdom; it is the "public' poetry of the ancient Tamils" (Ramanujan 1975:101).

In expanding his focus from the classical period to the modern, Ramanujan began to write of "an akam-puram, or domestic-public spectrum of folk genres," of which "the most akam, 'interior, private, familial,' in terms of teller and audience" are folktales told by women "in a kitchen while feeding the children" (1986:46). The world of akam is finally understood as a women's space, in which its own set of values and attitudes come into play, as counterposed against the male-dominated puram world; Ramanujan writes, "Genders are genres. The world of women is not the world of men" (1991b:53). With the most domestic scenario at one end, South Indian folk genres could be seen to range across a continuum of increasingly more public, and more male, performances, culminating in the theater: "Theater, the end-point in the continuum, is the most "puram, exterior, or public' of the genres" (Ramanujan 1991b:53). Ramanujan came to see these categories of akam and puram as simultaneously native and analytic and as a common cultural base that folk and classical traditions both share (Blackburn and Ramanujan 1986:13-14). Subsequently, other scholars have shifted the emphasis of Ramanujan's understanding of akam and puram from Tamil literature to the very organization of Tamil society itself: "This separation of the public and private spheres between men and women, respectively, pervades everything in Tamil society, including fiction and folk forms" (Pandian 1992:79); "as a cardinal principle of that very culture . . the Tamilians have divided the world into 'inner' (akam) and 'outer' (puram) categories" (Shulman 1985:6).

Given the deep ideological roots of this gendered separation between the spheres of domestic/private/familial/interior/female on the one hand and the civic/public/exterior/male on the other-a functional and symbolic ordering of the world that affects both the Tamil fictive landscape and its more mundane manifestations - the transgressions of the stage actress become all the more clear. She is engaged in performing in a most puram genre (the public theater), in a most public place (recall that Special Dramas are performed outdoors), and appears onstage alongside unknown men (strangers), yet speaks publicly of love, the most akam of all things.

This transgression of the ideology of separate spheres stigmatizes both male and female performers of Special Irama. For male artists, too, are engaging in transgressive behavior by moving so freely with public women. As a performance genre Special Drama contradicts the division into artistic spheres of akam and puram by employing both male and female artists onstage together. rather than following the practices of more traditional genres of Tamil folk theater. such as Terukkuttu (street theater), which is performed by all-male troupes. ${ }^{22}$ Special Drama is thus something of an anomaly among Tamil theatrical genres. 
It neither abides by traditional conventions of sex-segregated performance nor fully quits the traditional for the modern theatrical world of "social dramas." as staged in the more cosmopolitan capital city of Madras, with their fully realist acting conventions and all the modern technology of indoor theaters. Special Dramas present, instead, a somewhat modernized version of traditional mythological stories, stories of kings and queens, gods and goddesses, in traditional rural venues under the equally traditional rubric of temple festival entertainment for villages and small towns. ${ }^{23}$ In all these ways, Special Drama falls between the cracks of both the modern and the traditional.

This anomalous position of Special Drama itself in the world of Tamil theatrical forms bears directly on the stigma that Special Drama actresses face, in that both sets of transgressions have to do fundamentally with a kind of inappropriate mobility of relations. Stage actresses in Tamilnadu are stigmatized precisely for being too public and for moving out into the world beyond the bounds of proper. private, modest feminine behavior. Mean while. Special Drama artists as a whole are stigmatized for not maintaining the boundaries of properly separate spheres, creating instead (recalling Ramanujan's dictum) a genre that has no clear gender and mixes traditional and modern elements much as it mixes women and men.

I see the stigma confronting Special Drama actresses in Tamilnadu as having three highly interconnected dimensions, each of which stems from the notion of inappropriately mobile relations. Here I can offer only an all-too-brief gloss of the first two dimensions simply to suggest the larger context of the accusation; it is the third aspect that I reflect on in depth in this essay. The first is a problem with acting itself, with the very fact of mimetic fluidity (the problem that vexed Plato): acting involves an imitation of reality that all too easily alters reality, as actors inhabit false selves and take actions that threaten to make mobile that whole field of relations in which persons are otherwise socially situated-a poor uneducated woman is suddenly a matriarchal queen. brandishing a sword. ${ }^{24}$ The second dimension of the stigma involves the overly fluid of fstage behavior of Special Drama artists in employing fictive kin networks rather than maintaining normal, orderly, sanctioned kin relations: actors use kin terms across caste, class, and religious and ethnic boundaries in constructing their acting community, creating socially expedient relations between these normatively distinct identities when "in reality" there are none. Such identity shifts onstage (through mimesis) and off (through appropriative imitation) taint the reputation of the acting community as a whole and stigmatize it as excessively mobile-fluid, verging on the unstable - in a social realm that values highly the notion of each in his or her place. (A common Tamil proverb states. "Kattãtikku muraiyum illai, kolukkattaikku talaiyum illai" |Actors have no proper order, just as a Ganesh cake has no headl. Here, the topsy-turvy Ganesh cake, a homemade sweet of no particular shape, is likened to a perceived lack of proper social order among actors, who threaten to turn normal relations upside-down. $)^{25}$

This essay focuses on the third dimension of the stigma, a dimension that accrues specifically to actresses and not to actors: their publicness and mobility 
as they move about on the ground conducting their husiness. The form of this inappropriate mobility-actual travels through the public sphere on roads that lead actresses (rather than educated middle-class women) to the public stage-threatens to expose the fragility of the culturally naturalized division of gendered spheres into akam and puram. interior/home and exterior/world. Actresses move onto public stages to enact what are meant to be the most private of relations. With this added to the other two dimensions of stigma that haunt the acting community as a whole (mimetic fluidity and fluid kin relations), the actress finally is seen as most unsettling precisely in her unsettledness.

\section{Narrative Three: Regarding Traveling to a Drama in a Public Conveyance}

Bakkiyalakshmi and I had finally settled on a date for me to accompany her to a drama. Bakkiya was a seasoned actress in her fifties, and we were going to a village in an area well known to her from decades of performing throughout the region.

As this village was accessible by a main road, we were traveling by public bus (there is less excuse for the luxury of hiring a van when a venue can be reached by bus). All Tamil town buses, like those we took that night, have a women's side and a men's side. The words indicating which side is which are stenciled directly onto the walls of the bus. When traveling in a pair, two women need have very little interaction with unknown persons on a public bus, least of all with unknown men. We had none.

We left from Madurai in the early evening and traveled into the night. To reach the sponsoring village we had to change buses at two different stations. In the first station our change was quick and easy because the next bus was already loading when we arrived. We simply got up from our two-person seat on the women's side of the bus from Madurai and switched to another two-person seat on the women's side of the bus from Sivaganga.

At the second station our bus was not waiting. Bakkiya told me it would not come for another half an hour. We got off the bus, and she led me to a little food stall, one among many lining the road on the side of the bus station. There a man was making a common flamboyant dish, a specialty of the region called "egg parota." 26 Its preparation involves terrific energy on the part of the chef. He holds two metal tools-they are shaped more like axes than knives-and bangs them down onto a wide, flat metal skillet, over and over. rhythmically mixing and chopping parota and egg. It is the noisiest manner of food preparation I have ever encountered, entrancing as only an intensely loud barrage of sound can be, starting for a spell of deafening decibels at each new order and abruptly stopping again in equally deafening silence.

The chef at the stall we approached flashed a big smile at Bakkiyalakshmi. They knew each other. though I did not catch exactly how. He was at least 20 years her junior. She introduced me, and he immediately put down his tools and led us back through his stall into a small back room. In it was a desk, a chair, and a cot. The walls were painted royal blue. He made sure I was comfortably seated in the chair and returned to his metal axes and metal skillet. Bakkiya asked me 
whether I would like to eat, encouraging me to do so here rather than wait for whatever food the villagers had prepared. I agreed. She left the room, and I was alone.

I sat in that little room for what felt like a long time but could not have been more than 15 minutes. The wall of sound just beyond unmistakably delimited inside from outside. Where I was sitting was inside: blue walls swimming around me, a tide of deafening sound reaching me in waves. The other noises, voices. and commerce beyond the walls of that room were all outside.

I realized that even on this most public of routes, taking a public bus from a public bus stand two towns away from home, Bakkiya had secured a little private space, which that night she lent to me so that I could disappear into a respite of invisibility. I sat there feeling safe and tiny and simultaneously out of the loop and bored. How, I wondered, does Bakkiya feel when she sits here?

\section{The Actresses' Strategy of Imitating the Good Woman}

An actress's battle for reputation against the stigma of unsettledness that haunts the acting profession is constant, for the very organization of Special Drama depends on performers' mobility. Recall that each artist is contracted individually for each performance and that it is each artist's responsibility to get to and from each venue. One of a Special Drama actress's primary challenges is. thus, how to accomplish her public artistic business while accruing as little tainting publicness, on the way there, as possible.

For even an actress (by definition, as we have seen. a woman with a bad reputation) wants to establish as good a name for herself as possible. Why is this? What is the importance of a good name? In this there are two realms of concern, the first being the impact of her good name on an actress's private life, and the second being the impact of her reputation on her working life as a professional actress. The two are, of course, linked.

As Tamil women, actresses share an awareness of the dominant values concerning women in the society in which they themselves live as women. Erving Goffman, in his pathbreaking analysis of stigma (1963), makes clear the centrality of this point. He distinguishes stigmatized persons from "normals," in any. given social situation, by noting that stigma arises from the perception of "an undesired differentness" from the norm. while "normals" themselves are simply' "those who do not depart negatively from the particular expectations at issue" in a given social context (1963:5). Goffman writes (and here his we voices the "normal" point of view), "The stigmati»d individual tends to hold the same beliefs about identity that we do; this is a pivotal fact. ... The standards he has incorporated from the wider society equip him to be intimately alive to what others see as his failing. ... Shame becomes a central possibility" (1963:7).

The stigma on actresses similarly hespeaks a concern of all women in Tamil society: to avoid shame, even a woman who inhabits such a stigmaticed identity" continues to gauge her own actions in relation to those of "normal" women, that is, in terms of what is considered normal behavior for a Tamil woman. She internalizes the same identity beliefs as other women. Thus, an actress may be as 
concerned to maintain a good name in her private life as is any woman within a society that accords a woman's good name such high value (see note 8 for the further ramifications of this internalization for actresses).

Regarding the second realm of concern, the actress's professional and economic life, I find James Scott's discussion of the relation of class to reputation useful. Scott asks and answers the question (in relation to agrarian peasants, in his work) as follows:

How important is a good name? Or. to put it the other way around, what is the cost of a bad name? The answer unfortunately depends a great deal on who you are. for the cost of a bad name hinges directly on the social and economic sanctions that can be brought into play to punish its bearer. In class terms, one must ask how dependent the poor are on the good opinion of the rich. . . A good name is something like a social insurance policy for the poor against the thousand contingencies of agrarian life. [1985:24, emphasis added]

An actress's reputation qua actress, as we have seen, is intricately bound up with her economic life. This is inseparable from her life as a Tamil woman. For though she may be a "bad woman" by virtue of her profession, in that very professional life. rather ironically, an actress is charged with enacting scenes of Tamil life onstage that incessantly require her to embody and voice normative moral expectations for Tamil women. Onstage, actresses must be able to speak to the overarching concerns with reputation that face all Tamil women, whether they are enacting the "good" Heroine role or the "bad" Dancer role. ${ }^{27}$ A thorough knowledge of this moral value system for gauging a woman's reputation precedes the ability to act either of these roles. Thus, actresses are fluent in this moral system, such that even if they are not able to actually be "good women" offstage (which they nevertheless continue to attempt), they can play them onstage; furthermore, it is their ability to play these roles onstage that grants them good reputations as actresses.

Thus, for a good reputation, whether on- or offstage, actresses put similar skills to work. In Tamilnadu today, middle-class women who want to maintain their reputations as good women while nevertheless venturing out into the public sphere are able to use the strategy Chatterjee documents, as we have seen, for middle-class Bengali women of the late 19th and early 20th centuries: displacing the boundaries of the home from an external, physical spatial relation onto a more flexible, internal psychic domain. Special Drama actresses, however, as members of the Tamil urban poor, are women who never had such proper middle-class homes in the first place. ${ }^{28}$ For these actresses, the task of attaining the qualities of the good woman-still defined by the virtues of domesticity-becomes one of imitation and mimesis. In other words, attempts to raise their reputations in the sphere of their domestic lives require that actresses extend their acting skills. Actresses who aspire to good reputations, offistage as well as on, must "act" the role of higher-class women. Both onstage and off, they enact normative women's roles. 
In their offstage attempts to garner whatever respect may be possible to them under these conditions, actresses employ strategies that make quotidian use of their mimetic skill. In their daily practice of public journeys, these women constantly, vigilantly strive to re-create, at least in appearance, the very physical confines of "good" feminine domesticity. What I am suggesting, in short, is that Special Drama actresses attempt to better their reputations as women by acting, even while offstage, on the dominant script of respectable femininity quite literally: by seeking to make their public travels offstage conform as closely as possible to the physical strictures, and psychic structures, of middle-class feminine domesticity.

In moving with Special Drama actresses through the streets of Tamilnadu. I saw them creating structures of enclosure (structures of the interior) even in the most public of places. These deceptively small structures of enclosure-the cardboard-backed calendars that substitute for their own bodies in shops. or the interiors of vans, or the little rooms behind street stalls in which they take respite-make up what I would characterize as spaces in which actresses subtly renegotiate their status through a strategy of expansion. The creation of such spaces effectively expands the category of properly domestic, feminine interior space to subversively include actresses, the very women who otherwise, and by definition, would have no access to such a domestic identity. Through the creation of such small, secluded spaces actresses force their inclusion as potentially "good" women into a calculus of moral virtues that otherwise categorically cxcludes them. ${ }^{29}$

Traveling with these women, I experienced viscerally how a dominant "inside/outside" dichotomy of "good/bad" morality informs their every journey. and I grew to appreciate their patient, understated, and expansive response to this oppressive climate. As we traveled. actresses erected enclosures that were their own exclusive, interior spaces-spaces that slyly appropriated for them a dominant strategy of exclusion everywhere we went. They strung together little islands, havens of familiarity, and hopped from one to the next as a means of remaining protected while moving through the outside.

\section{Narrative Four: Regarding Spatial Arrangements at a Drama Site}

When artists reach the performance venue, an outdoor stage has already' been erected at the site. The stage is a raised rectangular platform. often with a dirt floor, with palm-frond thatching for three walls and the ceiling. ${ }^{30}$ Specifications for the stage require a large playing area and an equally roomy backstage to which the actors may retire when they are not onstage. Actors call the playing space onstage "()utside" ( $\left(c^{\prime} / i, \bar{e}\right)$ and the backstage resting space "inside" (ulle $)$.

Thus, a central feature of all Special Drama venues is that there is a definite demarcation between inside and outside, between a public space where actors are visible to all and a private space into which they may disappear. This demarcation is provided by the painted canvases known as "scene settings." which stretch from ceiling to floor and are rolled and unrolled for scene changes throughout the night. 


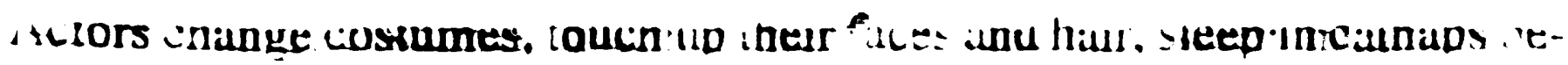

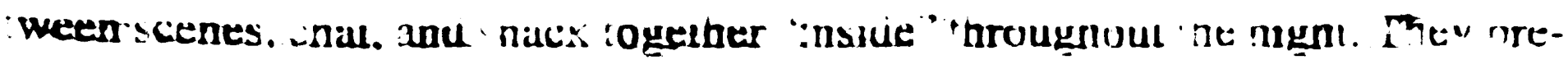

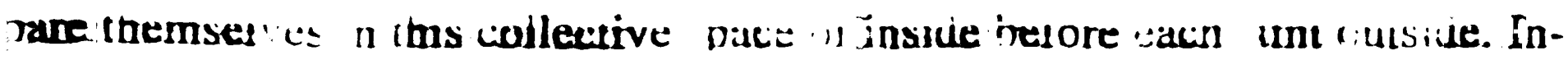

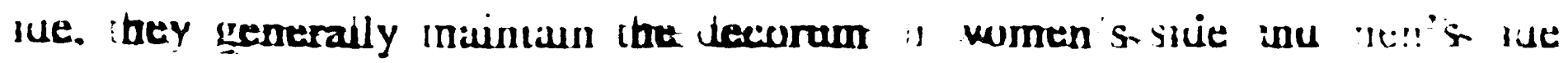

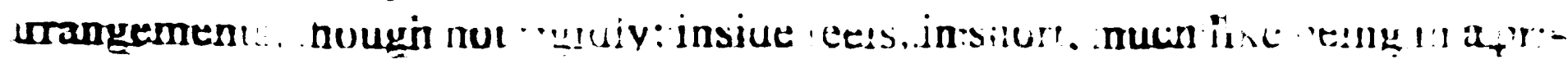

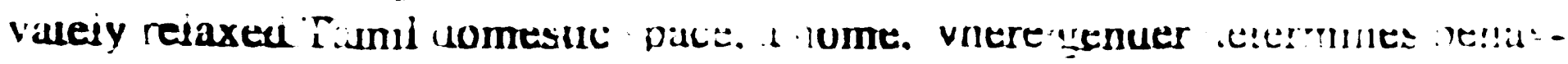

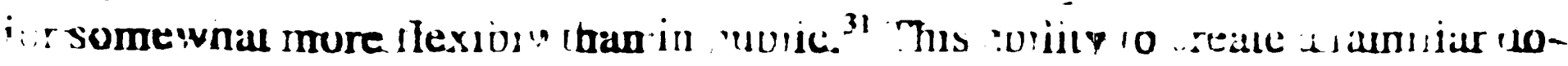

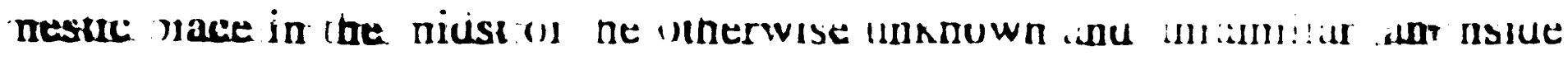

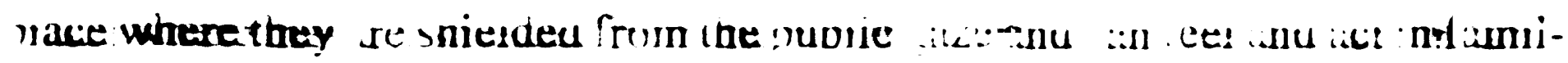

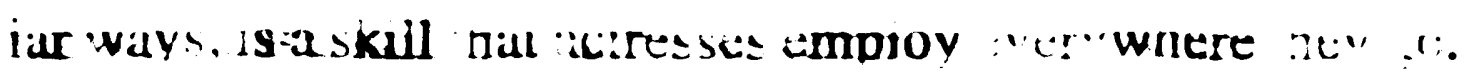

Eveninsiue:the !nsicie.nse!t. cr :xampte, alciresses :nantaun ne: tamilar

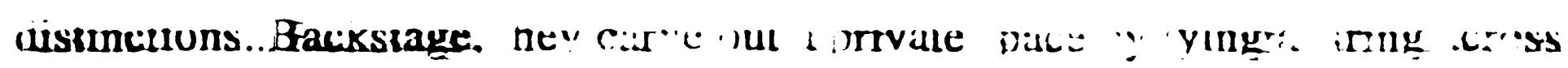

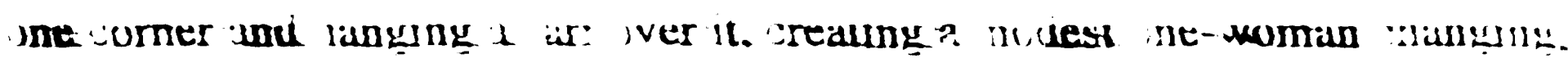
sorner.

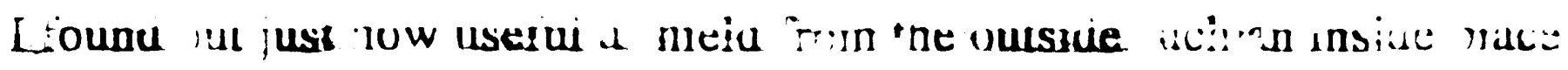

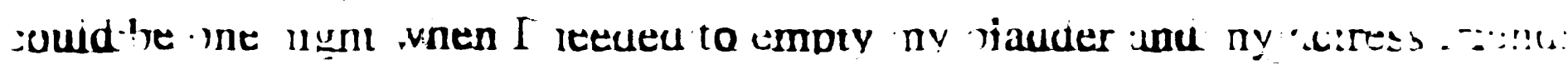

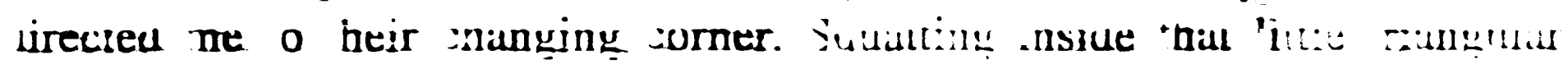

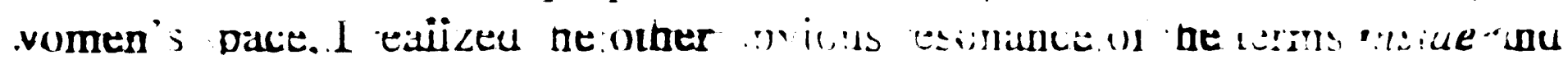

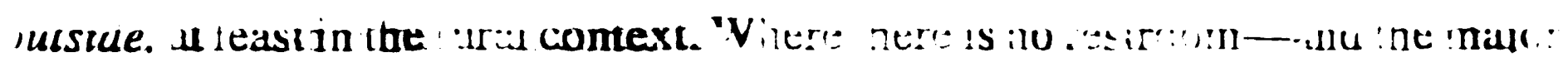

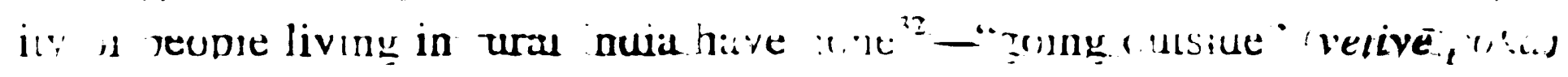

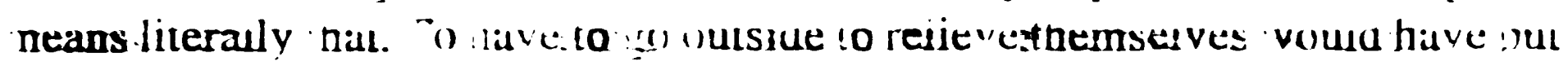

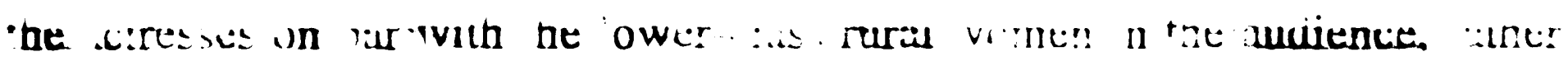

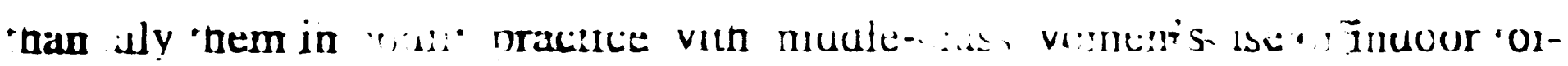

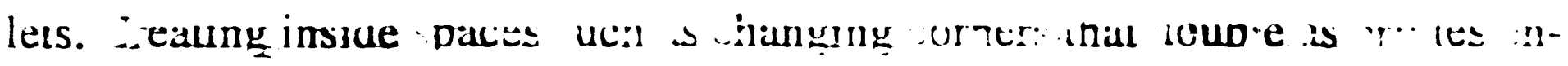

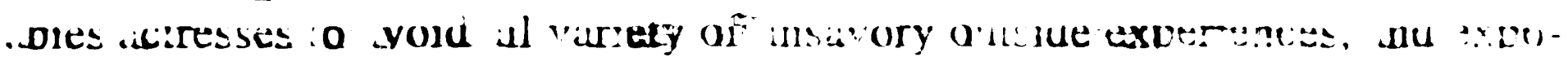

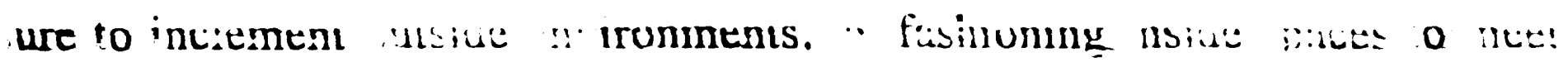

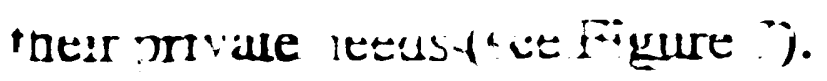

\section{Thesretioad fictiunus}

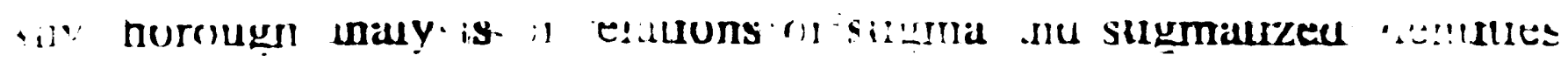

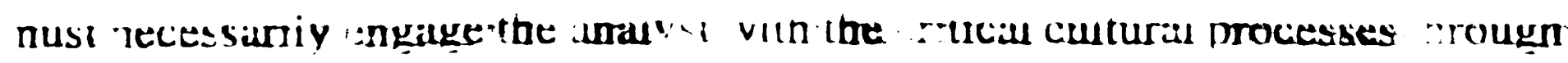

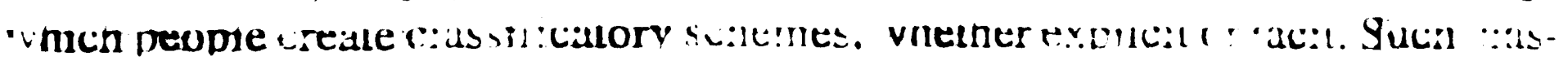

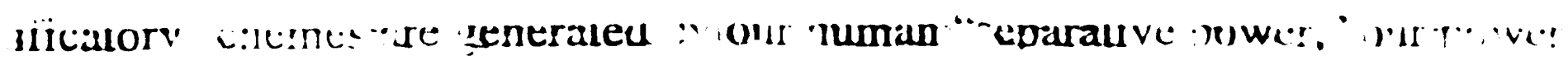

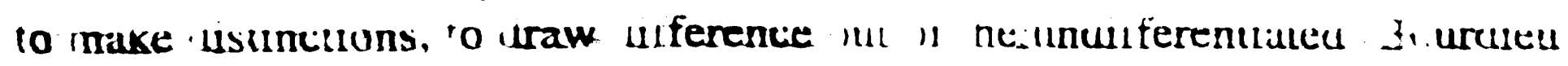

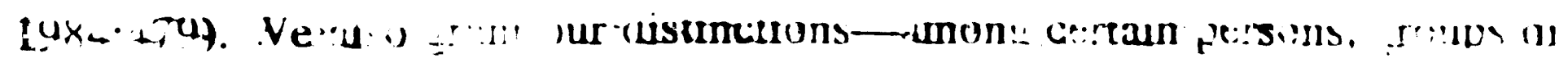

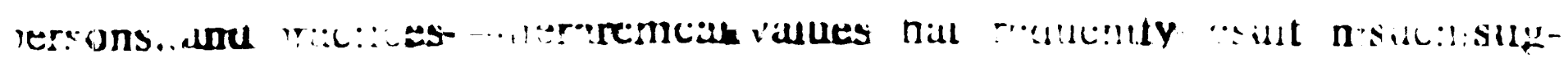

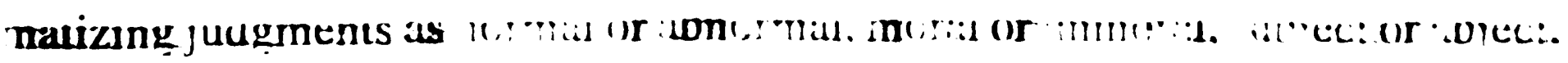

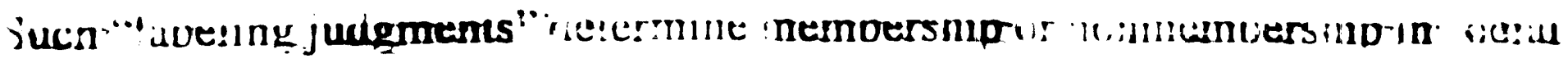

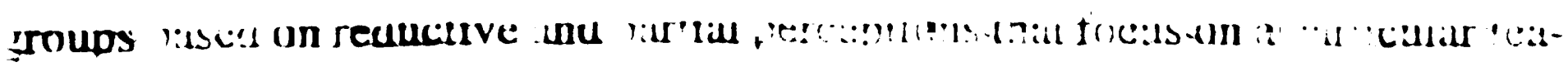

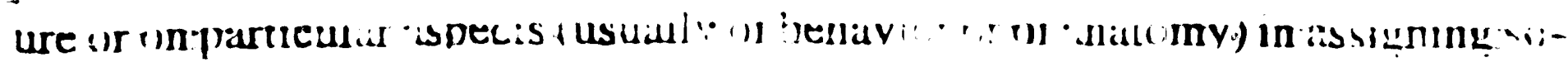

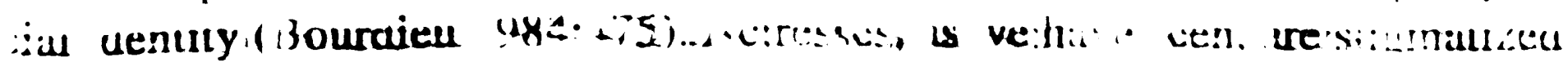

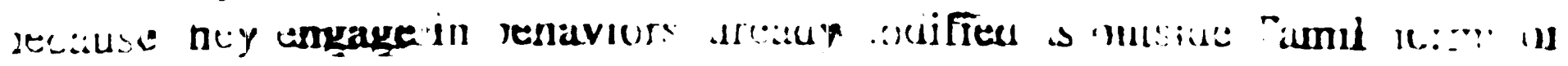

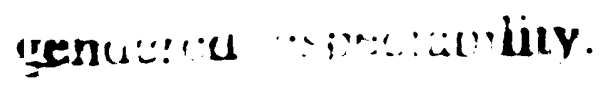

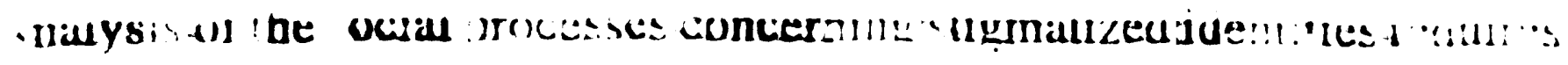

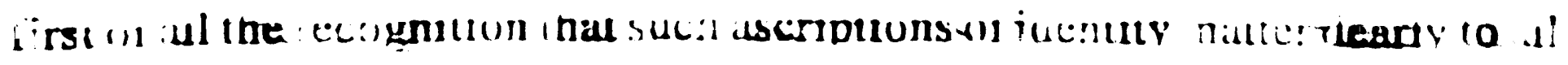




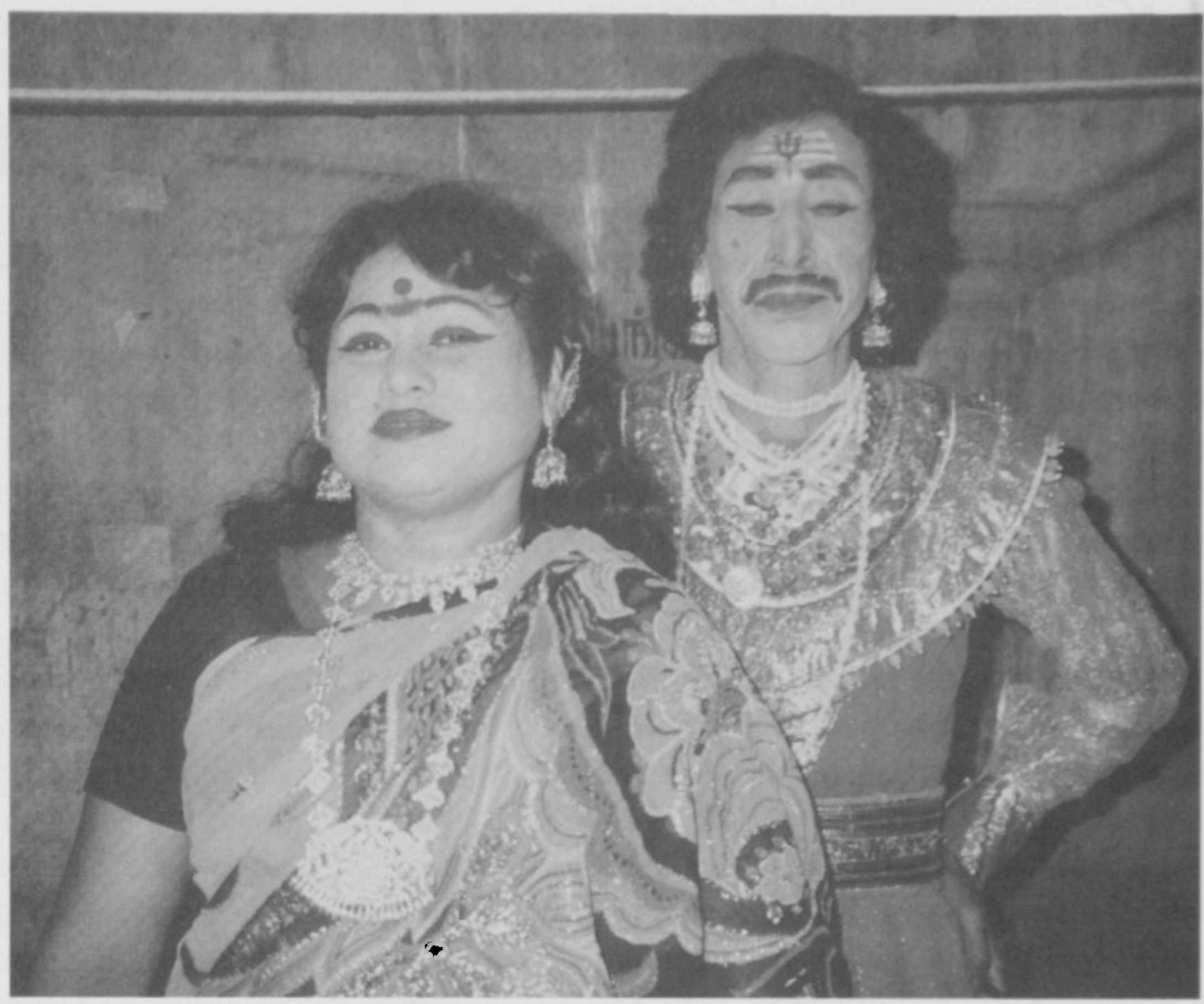

Figure 7

Backstage at a Special Drama, 1993. The artists are in costume.

involved. Bourdieu writes, "Every real inquiry into the divisions of the social world has to analyze the interests associated with membership or non-membership," for "social identity is the stake in a struggle" (1984:476): "What is at stake in the struggles about the meaning of the social world is power over the classificatory schemes and systems which are the basis of the representations of the groups and therefore of their mobilization and demobilization" within the social world (1984:479).

Thus, the analysis of social stigma runs right into the heart of a rich thicket of questions regarding the social workings of hegemony and consent, power and resistance. In struggling with their social identity, actresses seem both to collaborate with and to resist the given terms of the world in which they act; indeed, their struggles are shot through with ambivalence and ambiguity. Sherry Ortner (1995) argues that such ambivalence is a part of resistance itself; I want to explore the quality and character of such ambivalence in Special Drama actresses' lives.

Thinking about the variety of embodied, on-the-ground negotiations of their stigmatized identity that I have encountered among Special Drama actresses, through the kinds of experiences I write of in this essay, has led me to recognize the wide range of possible strategies people may use to negotiate stigma. These strategies are often not overtly stated but, rather, exist as "dispositions" and as 
the "schemes of perception and thought" that inform action: "The principle of this structuring activity is not . . . a system of universal forms and categories but a system of internalized, embodied schemes which, having been constituted in the course of collective history, are acquired in the course of individual history and function in their practical state, for practice" (Bourdieu 1984:467). Such internalized and embodied schemes are capable of generating infinite practices "without those schemes ever being constituted as explicit principles" (Bourdicu 1977:16).

Actresses' embodied negotiations of the public sphere in relation to their work-their roadwork. if you will-are the subject of this essay. I have analyzed their embodied strategies for dealing with their stigmatized social position not simply by questioning actresses directly about how they think of their social position but, rather. by observing what they $d o$, within the context and in the light of broader classificatory schemes-distinctions such as akam and puram, ulle and veliye - operative in their social world. My attempts to understand actresses' roadwork are classically ethnographic, in that I treat my own experience of Special Drama actresses' roadwork practices as central to identifying how and what I hope to understand. As Ortner notes, "Ethnography ... has always meant the attempt to understand another life world using the self-as much of it as possible-as the instrument of knowing" (1995:173).

To some extent, then, this essay is part of a larger Foucauldian endeavor of teaching ourselves, as analysts, to recognize the variety and multiplicity of responses to power. ${ }^{33}$ These responses include both resistance and collaboration; indeed, in the work of many theorists the distinction itself has become difficult to maintain, and rightly so (see the discussion in Ortner 1995:175-176). Resistance and compliance shade into each other, for the ultimate meaning of an act depends so entirely on context, and contexts themselves change and evolve through these very same acts. Moreover, all too often compliance is the most effective way to resist an oppressive power.

I think it behooves us, as analysts, to continue to enlarge our understanding of the myriad possible human responses to situations of unequal power. I am particularly interested in the role that relations of stigma play in such situations. Recognizing the intense particularity of each stigma should serve to remind us of the only truly generalizable feature of ethnography: the embeddedness of human action in local schemer of meaning.

Scholars have written extensively on this subject. Writing specifically about the resistance of subordinate classes, a resistance that is "close to the ground, rooted firmly in the homely but meaningful realities of daily experience" (1985:348), Scott documents both large-scale revolts and the far more common or garden-variety evasive and defensive "weapons of the weak." which include "foot dragging. dissimulation, desertion, false compliance, feigned ignorance, slander. arson, sabotige and so on" (1985:xvi). Christıne Pelyer White has suggested that we add an inventory of "everyday forms of collaboration" to balance this list of "everyday forms of resistance." for "hoth exist. hoth are important" (1986:56, cited in Ortner 1995:176). Abandoning the form of the list 
for a more conceptual model, Comaroff and Comaroff suggest that resistance itself is "less a thing than a continuum of possibility, a range of means by which those who see themselves as dispossessed and disempowered seek, through their own agency, to regain mastery over their lives" (1993:17).

The Comaroffs offer a useful typology of all potential forms of resistant acts that ranges "across the spectrum from the most inchoate, individual, informal modes of resistance toward the more formal, public, obviously 'political' expressions of protest" (1993:27). This continuum has a gendered aspect, for the former end-often characterized as "everyday, domestic defiance"-is, not surprisingly, home to those tactics and forms of resistance that women most frequently employ, having less access to more organized forms (Comaroff and Comaroff 1993:38). Foucault himself suggests that the tendency, since the 19th century, to judge processes of struggle only in terms of contradiction is a theoretical impoverishment that has led to dissolving all the specific problems of struggle "into the meagre logic of contradiction" (1980:143).

Whatever the form in which we conceive of it, then, our understanding of the range of means people use to seek mastery over their lives must include assimilationist collaborative strategies, which often shade into everyday forms of resistance, as well as outright refusals to collaborate in the form of revolts, rebellions, and separatist practices. In my view, the most assiduous documentation of assimilationist collaborative strategies remains Goffman's study of stigma (1963), in which he discusses such adaptive actions as passing. "covering" through the use of "disidentifiers," restricting one"s quotidian movement (one"s "daily rounds") both geographically and socially. splitting one's discursive worlds through strategic silences (cf. Scott's "hidden transcripts" [1990]). avoiding intimacy, and in general lessening the obtrusiveness of a given stigma on a given social scene by any available means.

I understand Special Drama actresses' attempts to ease their road in the Tamil public sphere-by expanding otherwise stigmatizing gendered norms to include themselves-as an adaptive practice that is both compliant as necessary and resistant where possible. To put it more succinctly, this roadwork is well attuned to their social world. While the schemes they employ on the road reiterate. and mimic, the forms of hegemonic power in Tamil society, the actresses" deployment of these schemes to ease their own road allows them at least some degree of circumstantial control. In their attempts to comply with the dominant gendered dichotomy of akam and puram that organises the Tamil world. actresses are ambiguously faithful and subtly inexact. To use Judith Butler's terminology, their roadwork is built out of "repetitions of hegemonic forms of power which fail to repeat loyally and. in that failure. open possibilities for resignifying the terms of violation" (1993:124). Through their embodied practices, actresses comply with the powers that stigmatize them only in such a way that their perceived compliance manages to expand their possibilities of making their home in the world or, at least, of making what home there is for stigmati/ed women in the Tamil social world somewhat more comfortable. As such, the roadwork of actresses is diagnostic of the complex particularities of relations of 
class and power in the Tamil sex/gender system (on using resistance, broadly conceived, as a diagnostic of power, see Abu-Lughod 1990).

In this essay I have attempted to wed the insights generated by my ethnographic experience to this set of critical approaches to analyzing relations of consent and resistance. Moving with actresses. I experienced an oscillation between havens of safety and stretches of painful overexposure. I have here included my own experiences of vacillating between comfort and discomfort as a way of beginning to understand actresses' experiences on the road. As I traveled with them, I began to make my own embodied sense of their roadwork, of its system of signs and dispositions, indeed of the "imaginative universe within which their acts are signs" (Geertz 1973:13). I understand my feelings during our travels as a set of signs that now signify to me, when I analyze them in the Tamil terms akam and puram (interior/exterior, domestic/public, inside/outside, invisible/visible)—which are the overarching context of actresses' roadwork-that I had begun to understand viscerally what was at stake for actresses when traveling through the public sphere. I was engaging in the famous ethnographic work of "deep hanging-out" (Rosaldo. quoted in Clifford 1997:188), through which I began to understand the character of lived experience among actresses. Examining my own experience of being with Special Drama actresses-on their turf and in their terms-allows me additional insight into their experiences of being "other" in the context of the contemporary Tamil public sphere.

\section{Narrative Five: Regarding Traveling Home in the Morning}

In Madurai I lived with an actress named Jansirani. The apartment building where we lived was smack in the middle of that little two-block radius of the Special Drama business district. Most Madurai actresses try to live as near as possible to this center, which minimizes the distance of their daily travels between home and a van or home and the central bus stand. ${ }^{34}$ Living in the center of town reduces their traversal of outsides and shortens the distance between insides.

The majority of male actors, on the other hand, still live in their natal villages most of the year and only stay in Madurai during the drama season. when they rent rooms in lodges in the center of town. Lodges are notorious "bad" nightlife spots, such that, for a woman with an eye to her reputation, being seen in one (let alone actually staying the night in one) is not a viable option.

Jansi and I returned together from a drama one morning by bus, sleeping: against each other in our seat. We arrived at the Madurai station just before 7 a.m.. tried surreptitiously to unrumple ourselves, smoothed down our saris. and began walking from the central hus stand to home, a distance of about five blocks.

We walked briskly through the streets. Jansi was moving very purposefully toward home. I stepped outside myself for a moment to wonder what we looked like: Does Jansi look like a woman who simply rose carly this morning? do I (not that I ever look simply like any woman here)? Tamil women riving early at home do things around their houses, sacred ritual things, the most visible to passersby 
being making kolams, geometric patterns in rice powder that are negotiations of light lines and dark ground at the entranceways of the houses, where street touches home. ${ }^{35}$ Kolams are one of so many respectable female daily efforts to keep the street from contaminating the home, to purify inner space and separate it from the outside. Were we, at that moment, the embodiment of the chaotic, disorderly, outside element? The very fact that we were not at home making kolams suddenly seemed yet another proof of this same distinction. Was it obvious that we had been riding a bus, sitting up all night. our faces bearing as many pressed wrinkles as our saris? What did people think when they saw us?

This felt to me like a particularly vulnerable moment, though at the time I could not understand why. Rationally, the threat of the kind of danger I was familiar with from generic travels as a woman was over: night was over. we were back on familiar territory, and it was a properly respectable hour of the morning to be out and about. But I saw, too, how tired Jansi was and how she had that barely containable kind of morning giddiness that comes from staying up all night. I felt scared that everything we had gone through was apparent on us: or was I perhaps picking up her fear as she walked. fast, not stopping to say anything to anyone? I realize now that this was a particularly vulnerable moment for her, a moment of separation from the group: we were no longer in that cocoon of sorts created by all the actors together, within the inside spaces of their night world and their street-side network of known people. Suddenly. we were two tired women alone on the street in the broad daylight, which glinted off the stray specks of green and pink glitter still stuck to Jansi's eyelids. and I felt exposed and confused, hurrying after Jansi, who was heading home so fast.

\section{Conclusion}

My own feelings when traveling with actresses reveal an unexpected sense of relief bordering on euphoria at finding havens of invisibility and familiar interiority, as well as a concomitant growing trepidation at being caught alone in public, be it day or night. In narrating these tales from the circuit of actresses' travels between booking shops, vans, buses, backstage spaces, and roads home. I have spoken of instances during which I felt uncomfortably "other." as well as of times when I felt included like family; occasions when I felt invisible but somehow safe; and still others during which I felt exposed and confused. While some of the sense of marginality and dislocation that pervaded my travels with actresses may have stemmed from my own psychology and cultural baggage. I have been interested here in how I began to experience their roadwork as a sensible embodied practice. ${ }^{36}$

My main aim for the narratives, however. has been to use them to illustrate the artistry of actresses' roadwork. Actresses attempt to resignify and resituate their own social position within a dominant system that persistently casts them as stigmatized other. I have attempted to show how Special Drama actresses struggle to conform to the dominant terms of gendered respectability while also suggesting that. in so doing, they subtly alter-by refiguring-these organi/ing terms themselves. Their struggle readily exposes, at least to me, the extent to 
which the internalization of a model of femininity based on domestic virtues affects women differently in respect to their class and social status. The internaliration of a femininity based unproblematically on a securely domestic identity is a class-based privilege to which actresses by definition do not have access. I have suggested that the roadwork of actresses is a hybrid of resistance and complicity, an attuned and adaptive practice. I have also noted its resignifying potential; through their strategy of expansion, actresses include themselves in the category "good women," to some extent, then, redefining the category.

\section{Epilogue: Striking the Stage}

Beyond describing this adaptive practice and indicating its potential, the question of the actual effects of these practices remains: Is resignification merely a possibility, or do these practices actually effect a more fundamental change in the underlying circumstances of stigmatized Tamil women's lives? Viewed in the harshest, most pessimistic light, actresses' attempts to make their conduct conform to dominant Tamil discourses of "the home and the world" have something of the pathetic. gaudy tenor of linguistic hypercorrections. Their roadwork appears as an effort to conform that actually only highlights their real inability to do so, normative status being always already out of their reach. In this light, the actresses are laughable at best; at worst, they reinscribe their own stigma.

Yet clearly their roadwork strategies do help actresses in the short term: Special Drama actresses assert their right to moments of seclusion and secure them. Their practices on the road make travel less harrowing for these women. What is really in question, then, are the longer-term effects of these practices: Do they result in any broad-ranging effects on the underlying circumstances that stigmatize these women? And if so, when and in what guise would such effects be evident? What would be their nature?

Once a given practice becomes the object of ethnographic study, the question of its long-term effects in the world expands to includ: both its effects on the lives of its original practitioners and its effects on the lives of those who learn of it through the products of ethnographic practice. Thus, there are now two sets of people for whom the roadwork of Special Drama actresses is meaningful, albeit in very different ways: on the one hand, the actresses themselves and, on the other, ethnographers and readers. The long-term effects for both of these sets of people differ.

Regarding the long-term effects of these practices for the actresse's themselves, there are also two sources of opinion: the truculently pessimistic assessments of the actresses and the much more hopeful assessments of scholars. Many Special Drama actresses, in many different contexts, have spoken to me about their broad hopes for the future. I have also asked them specificillly if they envision a time when the quality of their lives might change. In general, even among the women who were earning well and whose hopes for the near future were high regarding their ability to live in greater relative financial ease within their lifetimes, actresses did not think that dominant Tamil attitudes toward their 
line of work would ever change. Over and again, informants answered my questions about their futures with an invocation of their hopes for their children. This was especially true if an actress had daughters. My friend Jansirani has two daughters, both of whom were teenagers in 1993. She told me frequently, "I pray that this road will end with me. Let it end with me. I don't want my daughters to enter this line or to go out onto this road." Most actresses I spoke with expressed the same wish. They had accepted that their profession would never be acceptable. In their quotidian practices, they continued to try to ease their road as best they could, but when they spoke of the future, it was clear that success resided in getting off this road entirely.

Scholars, on the other hand, voice more hope regarding the question of the long-term effects of even such complicitously resistant (resistantly complicitous?) practices. ${ }^{37}$ Scott is guardedly celebratory in his concluding remarks to his study of everyday forms of peasant resistance in Malaysia. He stresses that such are our current times that we must highly value the short-term strategic responses to oppression that do at least provide a modicum of the small decencies that matter so much to people in the day-to-day world. Scott argues that the worldwide failure of grandiose movements for social change is all the more reason "to respect the weapons of the weak" and

to see in the tenacity of self-preservation-in ridicule, in truculence, in irony, in petty acts of noncompliance, in foot dragging, in dissimulation. in resistant mutuality, in the disbelief in elite homilies. in the steady, grinding efforts to hold one's own against overwhelming odds-a spirit and practice that prevents the worst and promises something better. [1985:350]

What that "better" might be finds an optimistic seconding voice in the Comaroffs' assertion that inchoatc forms of everyday resistance inevitably "transform the consciousness of, and to one degree or another empower, those who engage in them" (1993:20).

I vacillate between "realist" (that is, skeptical) and "populist" (celebratory) views of the effectiveness of such relatively inchoate adaptive strategies as the roadwork of Special Drama actresses. For a long time I was unable to see anything hopeful in these activities; I felt that unless the actresses could articulate the larger problems and overtly attack the rigidities of the Tamil class/gender system as a whole, nothing truly "resistant" was going on here. I now recognize that change occurs in many different ways, and I am less inclined to privilege the verbal as a means of effecting it. I am still skeptical of what I sec as an overly optimistic assumption that inchoate forms of everyday resistance inevitubly transform consciousness, but I am increasingly open to asking how gestures of defiance (even those that are ostensibly gestures of compliance) might transform the consciousness of those who engage in them.

In invoking actresses' consciousness. I do not mean to imply either that they do think, or need think, of their own work in the same interpretive terms that I do. I am the one who constitutes their schemes as "roadwork." Actresses do not need to coin such a term; after all, they are not writing essays to be read 
by people unfamiliar with their social world-rather, they are living that world. What their lived practices can teach us-ethnographic readers and writersconstitutes a second level of potential long-term effects of their actions, a matter to which I return shortly.

I certainly hope that the significance of the everyday struggles of the disempowered, and the resignifications they entail, will prove cumulative and that the "longer-term, transnational impact" of localized populist struggles will be "to politicize and animate peripheral peoples everywhere in altogether new ways" (Comaroff and Comaroff 1993:16). But my hope is offset by the following caution.

Mimetic repetitions-sometimes even canonically nonloyal repetitions, such as the actresses practice - can easily serve to reinscribe rather than to subvert an established order. Here I am rephrasing a question posed separately both by the Comaroffs (1993:39) and by Judith Butler. Butler (prompted by misreadings of her own earlier work as overly celebratory) asks "whether parodying the dominant norms is enough to displace them" (1993:125). Her answer is to recall the ambivalence of human action as reflective of "the more general situation of being implicated in the regimes of power by which one is constituted and, hence, of being implicated in the very regimes of power that one opposes" (1993:125). The possibility of resignification and its ultimate effects are two different matters; as always, attempts to refigure social norms sometimes succeed and sometimes do not, and these outcomes resolve slowly. Must we then leave all judgments as to the effectiveness of such attempts to retrospect? Perhaps I am simply too impatient. I do think it is important to free ourselves of exclusively heroic models of action; from little things, big things grow (or might)—but from which small things? And will the nature of the new big things be any different from that of the old big things? These remain unanswered questions about the long-term effects of Special Drama actresses' roadwork on their own lives.

What then of the long-term effects of their roadwork practices on the ethnographer and her readers? This question concerns the goals of our practice of cultural anthropology. What do we make of our fieldwork experiences and what we learn from them of different ways of being? What do we make of all the rich ethnographic information we now share about poverty and its particularities, the gory details of class struggle, and the endless inventiveness of strategies for counteracting stigma?

Scott has called the ordinary weapons of relatively powerless groups Brechtian forms of class struggle (1985:xvi), and his invocation of a social critic whose medium was theater is well chosen. However, the strategies Scott documents are not "Brechtian" in any sense that suggests that these are themselves the political strategies Brecht advocates. Rather, Brecht's strategy was to put the struggles of the people onstage - and quite often his characters are women, most famously in the figure of Mother Courage but equally in the actions of the heroines of The Jewish Wife and The Good Woman of Sctzuan ${ }^{38}$ - to show us the material specificity of the human condition. Likewise, in anthropological fieldwork we experience the world differently for a time, living in other contexts, 
linking ourselves up with people whose subjectivities differ from our own. People do what people must, always in particular historical circumstances. Brecht's "epic theater" asks the audience to look directly at these conditions and to think about them: Mother Courage makes her living off of others dying! She is a military opportunist! She acts out of pure self-interest! The world is falling apart! Can you blame her? Would she always act this way? To change her, what must change? the world? Can we change that? Brecht stages these struggles not to suggest that they themselves are answers but only to prompt our further questions.

The burden of changing the conditions represented onstage then belongs to the audience: "The task of the epic theater, according to Brecht, is not so much the development of actions as the representation of conditions" (Benjamin 1969:150). Brecht's own theatrical and theoretical act of resistance was to oppose the notions of empathy and audience identification found in the dominant theatrical conventions of his day, Realism and Naturalism (as is still the case in ours). His aim was to change the audience's attitude: they should sit in their seats, puffing thoughtfully on their cigars, thinking about human history ("Can we persuade them to get out their cigars?" [Brecht 1964:39, 91-99]). The play should be an "object of instruction" (Brecht 1964:42). Viewing the human condition onstage becomes the audiences' rehearsal for action: when our time comes to act, may we have thought about our role first.

My own goals are similar: may the act of anthropological interpretation and representation serve to clarify our thinking regarding historical human conditions, both specifically and generally. In presenting Special Drama actresses moves and movements on public roads, my aim has been to document these conditions and to present how actresses have dealt with them. I study actresses' roadwork as a means of understanding the complexity of inequalities of power on the ground. Special Drama actresses work on, and in, a maze of roads. I watch them, on- and offstage, sometimes moving with them, to learn about their strategies for dealing with social value systems that stigmatize and exclude them. I cannot predict where their actions will ultimately lead them; nor can I predict where my representations of their actions will take me. What I have tried to do here is to critically consider the possibilities for further action, both theirs and mine, opened up by prior acions, both theirs and mine. Thinking, experiencing. and writing about actresses' roadwork is both my practice and my rehearsal for future action.

\section{Notes}

Acknowledgments. Primary thanks are due to Dan Segal. for his editorial encouragement and readiness to discuss substintive aspects of this essay, and to the four anonymous readers for Cultural Anthropology who gave an earlier version such careful critical thought.

I have previously presented the ethnographic core of this essay at the following conference venues: the 25th Annual Conference on South Asia. Madison. Wisconsin. October 19. 1996: the Association for Asian Studies 49th Annual Meetings, Chicago, March 
14. 1997; the Graduate Conference on Space in South Asia, University of Chicago. May 17. 1997; and the 2nd Annual South Asian Women's Conference. Los Angeles. September 20, 1997. I am grateful to my co-panelists at three of the four venues listed above, Mary Hancock, Kamala Visweswaran, and Malathi De Alwis, for the opportunity to present my ideas in the context of theirs. I give thanks again to our discussants (Carol Breckenridge in Madison, Nilanjana Chatterjee in Chicago, and Karen Leonard in L.A.) for their encouragement, as well as to the many supportive audience participants at these meetings. Arjun Appadurai early on offered me valuable editorial suggestions for expanding this material, which I have been able to effect only now.

To Catherine Brennan I am infinitely grateful: her consistently good-natured labor, clear thinking, and stupendous vocabulary have contributed appreciably to the final form of this essay. Additional thanks are due to Elizabeth Chin and Kelly McIntyre for their ongoing encouragement (and willingness to read over the summer).

Finally. I remain grateful to Jean Comaroff for her perseverance in encouraging me to continue questioning my own attitudes toward the meaning of the daily acts of Special Drama actresses; ours promises to be an ongoing conversation. to whose future installments I look forward. And for his ever keen and patient ear and inspiringly acute eye. I again thank my teacher and mentor, Bernard S. Cohn, who encouraged me early on to write as I liked.

1. "Special Drama" (Special Nātakam) is a 20th-century Tamil theatrical genre that began around the turn of the century. It is also known as "Music Drama." I discuss the nature and organization of Special Drama at length in the body of this essay. But briefly, the nominative adjective Special distinguishes this theatrical genre from other contemporary forms of Tamil theater, including Social Drama and Modern Drama, both of which are more urban genres of popular theater. Special Drama is generally performed on an outdoor stage erected in the local commons of a town or village or equally often at the intersection of two roads.

2. Rather than privileging the visual as the sole mode of perception valuable to social scientific method, I join a host of others (Bourdieu 1977; Fabian 1983; Jackson 1989: Myerhoff 1978: Turner 1985) in understanding "participant-observation" as an endeavor that engages the researcher"s whole person in perception. Along these lines, I particularly like Michael Jackson's proposal of a radically empirical method that entails "working through all five senses, and reflecting inwardly as well as observing outwardly" (1989:8). In this essay, I treat my own experiences as primary data, for. like Jackson, I define the experimental field here "as one of interactions and intersubjectivity" (1989:4). Such methods necessarily spark all manner of complex psychological relations between researchers and subjects, including transference, countertransference. identification. and disidentification. Rather than shy away from these complexities, I sec promise in recognizing that it is because of such human relations that anthropology is such a rich science. In Barbara Myerhoff's deceptively simple words. "You study what is happening to others by understanding what is going on in yourself" (quoted in Frank 1995:213).

3. In the tradition of memory training developed hy the 16th-century Jesuit priest Matteo Ricci. human memory is significantly aided by images that are "lively and not too static[:] they must arouse strong emotions" (Spence 1984:25-26).

4. Today, the majority of Special Dramas retell Hindu mythological stories and are performed at Hindu temple festivals, but there are also Christian dramas in the Special Drama repertory that are performed for Christian church festivals. The population breakdown of Tamilnadu by religious community is roughly 90 percent Hindu, 7 percent 
Muslim, and 3 percent Christian. Each of these religious communities is currently represented among both artists and audiences at Special Dramas, although Muslim doctrine frowns on such representations, and the overtly lslamic dramas that were part of the genre in its early decades are now rarely performed.

5. The 16 cities that serve as regional centers for the arrangement of Special Dramas are noted on the map in Figure 1. The city of Madurai is the oldest organizational center for Special Drama, and the actors association in Madurai is still referred to as the "mother" actors association. The history of Special Drama grows from early roots in Madurai and its nearby towns.

6. Madurai is an inland city in the south-central region of the state of Tamilnadu (the name means "Land of Tamil"), the southernmost state in India. Madurai is an ancient temple city that still figures largely as a Hindu pilgrimage site. A. K. Ramanujan has coined the term rurban to describe what he perceives as a notion, emergent in both classical and modern Tamil literature, of "a center continuous with the countryside" (1970:242); Madurai, a city frequently described as "an overgrown village," is paradigmatic of such a Tamil rurban center.

7. In marital negotiations, mothers actively participate. In drama negotiations, as this narrative seeks to illustrate, only men participate. Nevertheless, in both cases the woman whose life is at the center of the negotiation is curiously silent.

8. As the remainder of this essay should make clear, even these women who are the apotheosis of public women care intensely that they not be seen as such, especially locally, where they live, as is the case in the calendar shops in Madurai (for actresses who live in Madurai). As the not-within-ten-kilometers practice suggests, many actresses will not perform unless they are far enough away from their domestic lives (from where they are known, local women) that the consequences to their reputations decrease.

Why should women who perform publicly, whose reputations for modesty have already largely been shattered, nevertheless attempt to conform to normative codes of gendered virtue? It seems these are the only codes that matter and that a woman must deal with these in some way. For many actresses, the public sphere seems to be divided into a differentiated continuum of publicness, either relatively more or relatively less proximate to her domestic sphere. In her proximate public sphere, relatively close to her home, a woman's reputation is reflected directly in her domestic life as well as affected by it. In that more proximate sphere, a woman attempts to be seen as not an actress at all. In the less proximate public sphere, where the woman is known primarily as an actress, she will attempt to stave off the bad reputation through all the "roadwork" techniques and strategies I speak of in this essay. Thus, the same principles of womanly virtue affect her wherever she goes, though they may do so somewhat less immediately and less directly the further she gets from home. Distancing herself from her own home allows her to more easily create a fictive self "on the road" whose modesty is then signaled by her "on the road" actions.

9. Mr. Jeyaraman called himself a "power agent" (using the English terms). He reasoned that this is an appropriate epithet for his work because he does not directly book dramas, as does a drama agent, but, rather, is empowered by the artists to book dramas on their behalf with many drama agents.

10. Dell Hymes's preliminary definition of the concept of communicative competence is still relevant for the basic foundation I am laying here. Hymes sees linguistic competence as intimately engaged with cultural knowledge because, in addition to grammar, "a child acquires also a system of its use, regarding persons, places, purposes, other 
modes of communication, etc.-all the components of communicative events, together with attitudes and beliefs regarding them" (1974:75, cited in Briggs 1988:6).

11. The history of Indian attitudes toward têvatacis (literally, "female dancers in the service of God," most commonly transliterated, following British colonial convention, as devadasis) involves a series of waves of culture contact between the peoples of Europe and South Asia, from at least the 16th century to the present. This history of culture contact is shot through with moralistic misreadings, which in the case of the art form of dance eventually resulted in a sanitized reconstruction of "classical" South Indian dance, transforming it from ostensible origins in the dance of devadasis to the Bharata Natyam of today. Indira Peterson (2000) adds to the already existing histories of British attitudes toward the "nautch" (the word Buitish social reformers used to denote Indian dance) an exploration of the 18th-and 19th-century French and German fascination with the (im)morality of this female figure. Peterson stresses the markedly different attitudes that precolonial South Indians held toward the devadasi than those of the Europeans. Other important contributions to the reconstruction of this history include Erdman 1996, Kersenboom-Story 1987, and Marglin 1985.

12. The stigma of prostitution seems to vary far less cross-culturally than do the legal regulations concerning its practice. See Pheterson 1993 for a valuable discussion of how "actual whore life" differs from "the whore stigma" in the West. The stigma of prostitution, and the shame and dishonor it entails, is every where meant to deter women from work that could potentially empower them, at least financially if not also sexually and psychologically (Pheterson 1993); equally, sex worker rights activists argue that "empowering sex workers empowers all women, for the whore stigma is used to discipline women in general" (McClintock 1993:3). The extent to which the whore stigma structures dominant notions of middle-class women's morality cannot be overemphasized; nonprostitute women are socialized into a morality that is specifically middle class in ways they do not necessarily realize when, for example, they expect working women to refuse any and all work that might be construed as morally irresponsible, to which one sex worker has commented, "Morals like that require a budget" (McClintock 1993:8).

13. Despite the stigma on the acting profession as a whole for women, many more Tamil women are willing and eager to act on the screen than on the stage. Madras is filled with young women who are aspiring film starlets. The screen has a cachet that the stage does not have, as cinema stars manage to elevate otherwise stigmatizing behaviors into the realm of cultic fascination and allure. The alchemy that converts a Tamil actress into a cinematic superstar deserves a separate study and is yet unwritten; one key question for such a study would be the extent to which fame mitigates stigma, for whom, and to what effect. For not even a Tamil female cinema star can escape the popular logic by which her chosen profession proves that she is, at core, a "bad" woman. In a passage on the reputation of female Tamil cinema stars, Sara Dickey writes, "The basis for the stigma attached to actresses seems to be related primarily to the sentiment that no 'good woman' would display herself in public. ... nice women would not show themselves to the public, so these women must have been bad before they became actresses" (1993:63).

In Tamil cinema, as recent scholarship makes clear, actresses remain purveyors either of the bad road or of a fantasy wherein bad women still get the goods. Indeed, it seems more likely that it is the women in the cinema audience, rather than actresses, who experience relief from the realities of Tamil women's roles. M. S. S. Pandian suggests that Tamil films offer female audiences a "liminal experience" wherein "the rigidly imposed rules of society are relaxed for brief periods" (1992:81). Dickey similarly notes the escapist appeal of Tamil films for their audiences, as well as the extent to which "the 
pleasure of that escape derives from its roots in real-life and psychological stresses" (1993:175).

14. My fieldwork in Tamilnadu. September 1991-July 1993, was supported by fellowships from the American Institute for Indian Studies and the Fulbright Foundation. The research was conducted primarily in the district of Madurai but, as this essay makes clear, also involved numerous journeys throughout the state.

15. I do not know the proportionate relationship between the caste affiliations of Special Drama artists and the caste makeup of the state of Tamilnadu as a whole. I do know that a majority of Special Drama artists in Madurai are members of a caste that is likewise the numerical majority in the larger Madurai district of Tamilnadu, thus a numerically, and therefore politically, dominant (if originally fairly low) caste. This is a caste group that artists commonly refer to as "Serrvăr," which refers to persons of mixed (from the Tamil verb root Sër, "to combine or mix") birth in any combination of the three subcaste groups of the overarching caste group Mukkulattor.

16. For example, when the Saurashtrian community in the city of Madurai sponsored a week-long festival of entertainments in 1993, their preference was to hire artists from their ethnic and linguistic community. While all the events were conducted in Tamil, and many of the artists were ethnically Tamil, Saurashtrian artists did enjoy preferential hiring for these events.

17. By 1993 exchange rates, 75 rupees was equivalent to $\$ 3$ in U.S. currency, and 300 rupees, to $\$ 12$.

18. The reasons for this are manifold and deserve a separate essay; they include (1) the seasonal nature of the work (Special Dramas are performed only six months out of the year, from March to August), which requires living off savings for half a year; (2) the horribly exploitative terms of indigenous loan systems, which plunge many artists into debt that eats all their earnings; (3) the shorter span of actresses' artistic stage lives compared with that of male actors; (4) the nature of joint family finances coupled with chronic underemployment in Tamilnadu, such that a single high earner in a family supports many others who earn insufficiently; (5) "culture of poverty" apprehensions familiar among people who have grown up poor under capitalism, here involving overcompensatory overspending as soon as the individuals earn anything, not trusting savings institutions, and indiscriminate spending; and (6) the potential additional costs for prepared food, off-hours transportation, and cosmopolitan-style clothing that result from a female member working outside as an actress instead of remaining, for example. at home cooking.

19. In the United States, this whole realm of associations of course has had enormous popular culture appeal, from James Dean's Rebel without a Cause in the 1950s to the girl group TLC, whose album "Crazy, Sexy. Cool" propelled the group to fame in the 1990s. Regardless of the deluge of Western popular culture influences in India that has continued from the colonial through to the postcolonial era, such an "allure of the bad" seems not to have fundamentally affected a system of social values whereby goodness is the desired cooling balm in an overly hot and overly crowded cultural and geographic climate. But such metaphor mixing is dizzying, and the dangers of misinterpretation in attempting such a large discussion in a note are overwhelming. Instead I refer the reader to two studies of South Indian cinema that discuss the ubiquitous Tamil cinematic plot of a good Tamil man taming a young woman of her bad Western ways and thereby converting her to an acceptable loving wife (see Dickey 1993: Pandian 1992), as well as to an entirely different angle on the meanings of cool and hot in Hindu India in relation to sexuality in the ethnosociological work of McKim Marriott (1989.1998). On how "bad" 
social roles have nevertheless ironically offered a refuge of sorts for some Indian women historically, see Veena Oldenburg's essay on Lucknow courtesans, whose lives and practices Oldenburg celebrates as giving "a completely ironic slant to the notion of respectability" (1990:266).

20. "Ambassador" is the brand name of one of the first models of automobile manufactured in India.

21. Chatterjee's discussion of the specifically Indian paradigm of the actress as highly stigmatized public woman (1993:135-157) is well supplemented by Hansen (1992, 1999), as well as by Dickey (1993:61-64) and Pandian (1992:79-90). Of course, actresses were also paradigmatically stigmatized public women in Victorian England (Davis 1991; Walkowitz 1998), as well as in the earlier Elizabethan period (Howard 1994), a history that is by no means easily separable from its colonial sequelae under the Raj.

22. For more information on Terukkuttu, see Frasca 1990.

23. In the world of Tamil theater, the designation "modern" has generally meant the use of three specific elements of theatrical presentation: the proscenium arch, with its raised stage and side wings; the division of a play into acts and scenes; and the creation of sets for these scenes, generally in the form of painted backdrops (Kapur 1991; Karnad 1989).

24. In The Republic, Plato exposes his fear that spectators will copy any behavior actors model for them and that there is a great moral danger in allowing spectators to enjoy the imitative antics of actors "lest from enjoying the imitation, they come to enjoy the reality" (1992:395d). That is, there is no natural clear distinction in human experience, for Plato, between imitation and reality; what makes theater so potentially destructive is the ease of its transformative power over the reality he would so like to determine for his ideal city. Elin Diamond has called this fear the root of "Plato's loathing of the theater" (1992:391).

25. For a more detailed discussion of this proverb in relation to the stigma on actors, see Seizer 1997a.

26. Parota is a thin, layered flat bread.

27. Here the reader will. I trust, take my word on this, for space does not allow me to present ethnographic material regarding onstage matters in an essay focusing on offstage practices; for a discussion of the onstage dynamics and gendered debates in Special Drama, see Seizer 1997 b.

28. In employing this class term I follow Sara Dickey's model and understand the term urban poor to be "a cultural as well as an economic formation" (1993:10). In Dickey's definition the members of this class share three important features: "poverty, a persistent sense of financial insecurity, and a lack of sociopolitical power" (1993:10).

29. Note how the Special Drama actresses' tactic here for dealing with their difference from the norm - that of acting as if they were already included in a preexisting category intended to exclude them-differs significantly from a tactic that has recently been so central to U.S. "identity politics": the creation of discrete new categories of identity to help stigmatized persons locate themselves as "other." The actresses" tactic of expanding the category "good woman" (rather than accepting a definition of its contours that has them always already outside it) seems to employ the kind of "tactical misrecognition" (1999:106) that Jose Muñoz discusses as "disidentification," defined as "a survival strategy ... that is employed by a minority spectator . . to resist and confound socially prescriptive patterns of identification" (1999:28). Of course, any identification includes misrecognitions (Sedgwick 1990:61, cited in Muñoz 1999:8). Muñoz’s 
contribution to this arena is his vision for how to use dominant culture "as raw material to make a new world" (1999:196). Seeing oneself as capable of belonging where one is not meant to be and acting critically on that perception-acting on a "disidentificatory desire," in Muñoz's terms - treats the world as a place where relations of identification are as highly fluid, mobile, and destabilizing as Plato feared they were (see note 23); where imitation inspires life to truly resemble art; and where dominant, exclusive cultural categories become terms whose relational nature is suddenly malleable in human hands.

30. In fact, performers are the ones with the roof over their heads at these outdoor performances. The VIPs of a village often also manage to watch the drama from onstage. Thus, it is only the common villagers who are truly outside, sitting on the dirt. So in the regular relations actors set up for themselves on their nights out, they are the higheststatus people, the ones most "inside" even while performing in an outdoor theater. Performances serve in this regard to incarnate, onstage, a collective desire for higher status on the part of artists and provide a temporary social upgrade through the symbolics of spatial organization, which is not entirely unrelated to the actresses' moves (the central focus of this essay) to raise their social status through offstage spatial negotiations. For a further discussion of how social values map onto the Special Drama stage, see Seizer 1997a: ch. 6.

31. Some gender separations are also maintained in most Tamil homes, for example, women eat separately, after men. Likewise, backstage at a Special Drama event, women and men arrange their suitcases of costumes on separate sides of the available space and sit behind their open suitcases, each with a hand mirror propped in its lid, to apply their makeup.

32. According to Burns in the New York Times, "700 million of the country's 930 million people, having no toilets, either defecate into buckets or on open land" (1996).

33. Numerous scholars of society, culture, and history have significantly contributed to this endeavor in recent decades, among whom primary influences on my own work have been Comaroff and Comaroff (1993), Halperin (1995), Scott (1985. 1990), and Sedgwick (1990; Sedgwick and Frank 1995).

34. The towns and cities that Special Drama artists live in function as regional centers for the dense population of villages that surrounds them. Artists invariably live, and establish their cities' actors association headquarters, near central bus stations so that they can easily be contacted by villagers who travel to these regional centers on public buses to engage their services. The occupational need to live close to the central bus stations of the cities they occupy leads to the interesting phenomenon that Special Drama artists generally live in the "first" postal code area of their respective cities: the oldest urban neighborhoods, those established around public transportation lines. For example. in Madurai, Special Drama artists live in "Madurai-1" or the 625001 postal code, which includes both the main rail and bus stations; likewise, the postal code for the actors association in Karaikudi is simply "Karaikudi-1." Ramanujan's term rurban captures well the way artists live in urban settings precisely because they are continuous with their rural surroundings. Likewise, Oscar Lewis's coinage-describing the network of human exchange and interconnection that links persons in different villages in India as "a kind of rural cosmopolitanism" (1986:167)_describes well the kinds of links between persons in different places that are repeatedly forged and secured through the continued exchange of the services of people engaging in the network of Special Drama.

35. David Shulman writes of the kolam as a negotiation of the threshold hetween akam and puram as follows: 
The mistress of the house, or a daughter, or perhaps a trusted servant, has laid out this pattern upon arising in the morning: she may have selected a traditional design of geometric shapes intertwined, or, if her intentions are more elaborate, two peacocks, perhaps, emerging from a maze. One cannot enter the house without passing through this man-made [sic] focus of auspicious forces. which sets up a protective screen before the home. Of course, one cannot see the screen itself, but only its focal point at the threshold, the point at which it emerges into form-a complex form at that, carefully planned and executed, a reflection of some inner labyrinth externalized here at the boundary, the line dividing the inner and the outer, the pure from the chaotic. [1985:3]

36. I have written about certain of the complexities of my own subject position and identity in Tamilnadu in another essay; see Seizer 1995.

37. The Comaroffs discuss the split between the celebratory and realist positions that scholars have taken on questions of the long-term effects of resistance, noting the vigor of the ongoing argument between the two (1993:16).

38. There are particularly strong continuities between the dilemmas of Tamil actresses and those of Brecht's "good woman of Setzuan." Brecht's heroine experiences an ongoing conflict between a moral injunction to be "good" and her need to be "bad" in order to survive economically. Nor do the similarities stop there. To negotiate this conflict, Brecht's good woman also resorts to acting: she plays two versions of herself-good and bad-off against each other throughout the drama. (See Brecht 1947, 1955, 1965.)

\section{References Cited}

Abu-Lughod, Lila

1990 The Romance of Resistance: Tracing Transformations of Power through Bedouin Women. American Ethnologist 17(1):41-55.

Benjamin. Walter

1969[1939] What Is Epic Theater? In Illuminations. Harry Zohn, trans. Pp.

147-154. New York: Shocken Books.

Blackburn, Stuart, and A. K. Ramanujan

1986 Introduction. In Another Harmony: New Essays on the Folklore of India. Stuart Blackburn and A. K. Ramanujan, eds. Pp. 1-37. Berkeley: University of California Press.

Bourdieu, Pierre

1977 Outline of a Theory of Practice. Cambridge: Cambridge University Press.

1984 Distinction: A Social Critique of the Judgement of Taste. Richard Nice. trans.

Cambridge, MA: Harvard University Press.

Brecht, Bertolt

1947 The Good Woman of Setzuan. Eric Bentley, trans. New York: Grove Press.

1955 Mother Courage. Eric Bentley. trans. New York: Grove Press.

1964 Brecht on Theatre. John Willett, ed. and trans. New York: Hill and Wang

1965 The Jewish Wife. Eric Bentley, trans. New York: Grove Press.

Briggs, Charles L.

1988 Competence in Performance: The Creativity of Tradition in Mexicano Verbal

Art. Philadelphia: University of Pennsylvania Press.

Burns, John F.

1996 Accident or Mass Murder? India's Food-Poisoning Mystery. New York Times.

August 19.

Butler, Judith

1993 Bodies that Matter: (On the Discursive Limits of "Sex." New York: Routledge 
Chatterjee, Partha

1993 The Nation and Its Fragments: Colonial and Postcolonial Histories. Princeton:

Princeton University Press.

\section{Clifford, James}

1997 Spatial Practices: Fieldwork, Travel, and the Disciplining of Anthropology. In

Anthropological Locations: Boundaries and Grounds of a Field Science. Akhil

Gupta and James Ferguson, eds. Pp. 185-222. Berkeley: University of California Press.

Comaroff, John L., and Jean Comaroff

1993 Resistance and Rebellion in Black South Africa, 1830-1920: Awful Acts, Lawful Facts, and Illegal Imaginings on a Colonial Frontier. Proposal to the American Bar Foundation and the University of Chicago. Unpublished MS.

Cre-A

1992 Kriyãvin Tậkălat Tamil Akarăti (Dictionary of Contemporary Tamil). Madras: Cre-A.

Davis, Tracy C.

1991 Actresses as Working Women: Their Social Identity in Victorian Culture. New York: Routledge.

Diamond, Elin

1992 The Violence of "We": Politicizing Identification. In Critical Theory and Performance. Janelle G. Reinelt and Joseph R. Roach, eds. Pp. 390-398. Ann Arbor: University of Michigan Press.

\section{Dickey, Sara}

1993 Cinema and the Urban Poor in South India. Cambridge: Cambridge University Press.

\section{Erdman, Joan}

1996 Dance Discourses: Rethinking the History of the "Oriental Dance." In Moving Words: Rethinking Dance. Gay Morris, ed. Pp. 288-305. London: Routledge.

Fabian, Johannes

1983 Time and the Other: How Anthropology Makes Its Object. New York: Columbia University Press.

Fabricius, Johann Philip

1972 Tamil and English Dictionary. 4th rev. edition. Tranquebar, India: Evangelical Lutheran Mission Publishing House.

Foucault, Michel

1980 Power/Knowledge. Colin Gordon, ed.; Colin Gordon, Leo Marshall, John Mephan, and Kate Soper, trans. New York: Pantheon Books.

Frank, Gelya

1995 The Ethnographic Films of Barbara G. Myerhoff: Anthropology, Feminism, and the Politics of Jewish Identity. In Women Writing Culture. Ruth Behar and Deborah A. Gordon, eds. Pp. 207-232. Berkeley: University of California Press.

Frasca, Richard A.

1990 The Theater of the Mahabharata: Terukkuttu Performances in South India.

Honolulu: University of Hawaii Press.

Geertz, Clifford

1973 The Interpretation of Cultures. New York: Basic Books.

Goffman, Erving

1963 Stigma: Notes on the Management of Spoiled Identity. New York: Simon and Schuster. 
Halperin, David M.

1995 Saint Foucault: Towards a Gay Hagiography. Oxford: Oxford University Press.

Hansen, Kathryn

1992 Grounds for Play: The Nautankl Theatre of North India. Berkeley: University of California Press.

1999 Making Women Visible: Gender and Race Cross-Dressing in the Parsi Theatre. Theatre Journal 51(2):127-148.

Howard, Jean E.

1994 The Stage and Social Struggle in Early Modern England. New York: Routledge.

Hymes, Dell

1974 Foundations in Sociolinguistics: An Ethnographic Approach. Philadelphia:

University of Pennsylvania Press.

Jackson, Michael

1989 Paths toward a Clearing: Radical Empiricism and Ethnographic Inquiry.

Bloomington: Indiana University Press.

Kapur, Anuradha

1991 Notions of the Authentic. Journal of Arts and Ideas (New Delhi) 20-21 (March):85-107.

\section{Karnad, Girish}

1989 Theatre in India. Theme issue, "Another India," Daedalus: Journal of the American Academy of Arts and Sciences 118(4):331-352.

Kersenboom-Story, Saskia C.

1987 Nityasumangali: Devadasi Tradition in South India. Delhi: Motilal Banarsidass.

Lewis, Oscar

1986[1955] Peasant Culture in India and Mexico: A Comparative Analysis. Village India: Studies in the Little Community. Chicago: Midway Reprint Edition.

Marglin, Frederique Apffel

1985 Wives of the God-King: The Rituals of the Devadasis of Puri. Delhi: Oxford

University Press.

Marriott, McKim

1989 Constructing an Indian Ethnosociology. Contributions to Indian Sociology 23(1): $1-40$.

1998 The Female Family Core Explored Ethnosociologically. Contributions to In-

dian Sociology 32(2):279-303.

McClintock, Anne

1993 Sex Workers and Sex Work: Introduction. Social Text 37:1-10.

Muñoz, Jose Esteban

1999 Disidentifications: Queers of Color and the Performance of Politics. Minne-

apolis: University of Minnesota Press.

Myerhoff, Barbara

1978 Number Our Days. New York: E. P. Dutton.

Oldenburg, Veena Talwar

1990 Lifestyle as Resistance: The Case of the Courtesans of Lucknow, India. Femi-

nist Studies 16(2):259-288. 
Ortner, Sherry

1995 Resistance and the Problem of Ethnographic Refusal. Comparative Studies in

History and Society 37(1) January: 173-193.

Pandian, M. S. S.

1992 The Image Trap: M. G. Ramachandran in Film and Politics. New Delhi: Sage Publications.

Peterson, Indira Viswanathan

2000 Reading the Temple-Dancer as Sati: From South Indian Legend to Goethe's

Poem Der Gott und die Bajadere. Paper prepared for the meetings of the Association for Asian Studies, San Diego, March 11.

Pheterson, Gail

1993 The Whore Stigma: Female Dishonor and Male Unworthiness. Social Text 37:39-64.

Plato

1992 Republic. G. M. A. Grube, trans.; revised by C. D. C. Reeve. Indianapolis: Hackett Publishing Co.

Ramanujan, A. K.

1970 Towards an Anthology of City Images. In Urban India: Society, Space, and Image. Monograph and Occasional Papers Series, 10. Richard G. Fox, ed. Pp. 224-244. Durham: Duke University Program in Comparative Studies on Southern Asia.

1975[1967] The Interior Landscape: Love Poems from a Classical Tamil Anthology. Bloomington: Indiana University Press.

1985 Poems of Love and War. New York: Columbia University Press.

1986 Two Realms of Kannada Folklore. In Another Harmony: New Essays on the Folklore of India. Stuart Blackburn and A. K. Ramanujan, eds. Pp. 41-75. Berkeley: University of California Press.

1991a Three Hundred Ramayanas: Five Examples and Three Thoughts on Translation. In Many Ramayanas: The Diversity of a Narrative Tradition in South Asia. Paula Richman, ed. Pp. 22-49. Berkeley: University of California Press.

1991b Toward a Counter-System: Women's Tales. In Gender, Genre, and Power in South Asian Expressive Traditions. Arjun Appadurai, Frank J. Korom, and Margaret A. Mills, eds. Pp. 33-55. Philadelphia: University of Pennsylvania Press.

Ray, Satyajit, dir.

1984 The Home and the World. National Film Development Corporation of India, producer; Satyajit Ray, writer and dir.

Reynolds, Holy Baker

1980 The Auspicious Married Woman. In The Powers of Tamil Women. Susan S. Wadley, ed. Pp. 35-60. Syracuse: Maxwell School of Citizenship and Public Affairs. Syracuse University.

Sahlins, Marshall

1985 Islands of History. Chicago: University of Chicago Press.

Scott, James C.

1985 Weapons of the Weak: Everyday Forms of Peasant Resistance. New Haven:

Yale University Press.

1990 Domination and the Arts of Resistance: Hidden Transcripts. New Haven: Yale University Press.

Sedgwick. Eve Kosofsky

1990 The Epistemology of the Closet. Berkeley: University of California Press. 
Sedgwick. Eve Kosofisky. and Adam Frank

1995 Reading Silvan Tomkins. In Shame and Its Sisters: A Silvan Tomkins Reader.

Eve Kosofsky Sedgwick and Adam Frank, eds. Pp. 1-28. Durham: Duke University Press.

Seizer, Susan

1995 Paradoxes of Visibility in the Field: Rites of Queer Passage in Anthropology.

Public Culture 8(1):73-100.

1997a Dramatic License: Negotiating Stigma On and Off the Tamil Popular Stage.

Ph.D. dissertation, Department of Anthropology. University of Chicago.

$1997 \mathrm{~b}$ Jokes. Gender. and Discursive Distance on the Tamil Popular Stage. American Ethnologist 24(1):62-90.

Shulman, David Dean

1980 Tamil Temple Myths: Sacrifice and Divine Marriage in the South Indian Saiva Tradition. Princeton: Princeton University Press.

1985 The King and the Clown in South Indian Myth and Poetry. Princeton: Princeton University Press.

Spence, Honathan D.

1984 The Memory Palace of Matteo Ricci. New York: Viking Penguin.

Spivak, Gayatri Chakravorty

1995 Translator's Preface. In Imaginary Maps: Three Stories by Mahasweta Devi.

Gayatri Chakravorty Spivak, trans. Pp. xxiii-xxix. New York: Routledge.

Tagore, Rabindranath

1985[1915] The Home and the World. Surendranath Tagore, trans. London: Penguin Books.

Tamil Lexicon

1982 Tamil Lexicon. 6 vols. Madras: University of Madras.

Turner. Victor

1985 On the Edge of the Bush: Anthropology as Experience. Edith L. B. Turner, ed.

Tucson: University of Arizona Press.

Wadley, Susan S., ed.

1980 The Powers of Tamil Women. Syracuse: Maxwell School of Citizenship and Public Affairs.

Walkowitz, Judith R.

1998 Going Public: Shopping. Streetwalking, and Sexual Harassment in Victorian London`s West End. Representations 62 (spring): 1-30.

White, Christine Pelzer

1986 Everyday Resistance. Socialist Revolution and Rural Development: The Vietnamese Case. Journal of Peasant Studies 13(2):49-63. 